\title{
Precipitation linked to Atlantic moisture transport: clues to interpret Patagonian palaeoclimate
}

\author{
Eduardo Agosta ${ }^{1,2,3, *}$, Rosa Compagnucci ${ }^{3,4}$, Daniel Ariztegui ${ }^{5}$ \\ ${ }^{1}$ Facultad de Ciencias Fisicomatemáticas e Ingenierías, Pontificia Universidad Católica Argentina, \\ Alicia Moreau de Justo 1600, of. 301, C1107AFF Ciudad Autónoma de Buenos Aires, Argentina \\ ${ }^{2}$ Facultad de Ciencias Astronómicas y Geofísicas, Universidad Nacional de La Plata, Av. Centenario S/N, \\ Paseo del Bosque, 1900 La Plata, Argentina \\ ${ }^{3}$ Consejo Nacional de Investigaciones Científicas y Técnicas [CONICET], Av. Rivadavia 1917, \\ C1033AAJ Ciudad Autónoma de Buenos Aires, Argentina \\ ${ }^{4}$ Departamento de Ciencias de la Atmósfera y los Océanos, Facultad de Ciencias Exactas y Naturales, \\ Universidad de Buenos Aires, 1428 Ciudad Autónoma de Buenos Aires, Argentina \\ ${ }^{5}$ Earth and Environmental Sciences, University of Geneva, 1205 Geneva, Switzerland
}

\begin{abstract}
Westerlies are the main climatic feature in the mid-latitudes of the Southern Hemisphere (SH), driving the amount and distribution of precipitation. Patagonia is a vast region in South America's mid-latitudes, which encompasses 2 sub regions with highly distinct precipitation features. These two regions include wet Western Patagonia extending from the Pacific coast to the Andean highs (i.e. maximum elevations), and dry Eastern Patagonia situated leeward of the Andes in the Argentine steppe plains. Patagonia is influenced by strong mid-latitude westerlies throughout the year. Westerlies have been considered the unique driver of climate both in Western and Eastern Patagonia. This research is focused on the Lago Cardiel catchment area in central Eastern Patagonia. A significant link between precipitation in that region and local zonal moisture transport from the Atlantic was established. A fraction of intense precipitation was related to strong local westward moisture transport, partly as a consequence of slow-moving weather systems crossing over Patagonia. As long as a dipolar pattern of long-term precipitation anomaly was observed between dry central Western/Southern Patagonia and wet central Eastern Patagonia, it could be interpreted as due to enhanced synoptic easterly moisture flux from the Atlantic. Thus, the westerlies rule was broken at least under blocking-like flows, which induced moist easterlies. The relatively wet 1940 s exemplified this phenomenon. Such a conceptual framework can be applied to palaeoclimatic proxy record reconstructions as well as to general circulation model (GCM) outcomes for the late and mid-Holocene.
\end{abstract}

KEY WORDS: Southern Hemisphere - Westerlies - Patagonia - Synoptic-climatology · Lakes · Blocking flow Resale or republication not permitted without written consent of the publisher

\section{INTRODUCTION}

In one of his early expeditions to Patagonia, Charles Darwin wrote: 'One naturally asks why Eastern Patagonia should be condemned to perpetual sterility while the western side of the same country, in the same parallel of latitude, is injured by too much rain? The prevailing westerly winds, and the Andes, are the causes. The winds bring much moisture from the Pacific, but they leave it all (condensed) on the west side of the mountains ...' (Darwin 1839, p. 314).

Darwin's assertion was indeed grounded in climatological fact and represents a primitive formulation of the westerlies rule. Patagonia is a vast region in South America, located at mid-latitudes, south of $40^{\circ} \mathrm{S}$ (see Fig. 1), encompassing 2 sub regions that show highly 
distinct precipitation patterns: Western Patagonia, which extends from the Pacific coast to the Andean highs (i.e. maximum elevations) that rise up to $1500 \mathrm{~m}$ above sea level at these latitudes; and Eastern Patagonia, which is situated leeward of the Andes in the Argentine steppe plains towards the Atlantic. As a narrow ridge of land surrounded by large oceans, Patagonia is influenced by strong mid-latitude westerlies throughout the year (Garreaud et al. 2009).

Recent findings in Patagonia relate the leading mean tropospheric circulation patterns throughout the annual cycle behind prevailing precipitation patterns to changes in moisture budgets at monthly, seasonal and interannual scales. The precipitation patterns are actually ruled by the intensity of low-level westerly winds and their interaction with the Andes range (Aravena \& Luckman 2009, Berman et al. 2012, Garreaud et al. 2013, Lenaerts et al. 2014). In turn, the typical eastward-propagating synoptic systems (baroclinic disturbances embedded in the mean westerlies) are deeply perturbed by the Andean range, leading to orographic enhancement of synoptic-scale precipitation upstream of the mountains in Western Patagonia (Carrasco et al. 2002, Smith \& Evans 2007). The mean precipitation sharply decreases within a few tens of kilometers to the east downstream in Eastern Patagonia, leading to a dramatic disappearance of vegetation and a rain shadow that extends all the way to the Atlantic coast (Prohaska 1976, Carrasco et al. 2002). Thus, in Western Patagonia, the uplift of moist westerly winds leads to significant orographic rainfall in concert with frontal precipitation, whereas orographically forced subsidence over Eastern Patagonia produces dry, highly evaporative conditions (Berman et al. 2012). Therefore, the few precipitation events in this semiarid region are frequently connected to an incoming trough from the South Pacific; the same synoptic disturbance favours rainfall to the west of the Andes (Barrett et al. 2011). Furthermore, it is usually assumed that moisture inflow is from the Pacific and driven by the upper tropospheric trough (e.g. Smith \& Evans 2007, Barrett et al. 2009, among others). Using correlation maps between daily precipitation and $850 \mathrm{hPa}$ zonal and meridional wind components, Garreaud et al. (2013) showed that precipitation in Eastern Patagonia tends to be slightly more intense under weak westerlies. They also assumed that this can occur even under easterly flow, without performing further analysis of the assumption.

The relationship between precipitation and lowlevel winds, at both seasonal and interannual scales, stems from their association with the synoptic scale emerging from the aggregated effect of individual storms, and is particularly strong because of the mechanical effect of the Andes (windward uplift and leeside subsidence). Note, however, that none of the previous studies have proposed the possibility that air masses from the South Atlantic could be partly responsible for precipitation in the semiarid region of Eastern Patagonia, overcoming the drying effect of the prevailing westerlies. The only literature suggesting a link between increased precipitation and lowlevel winds from the Atlantic in Eastern Patagonia is an early climatic study performed by Barros \& Mattio (1978). They described a relatively wet period that occurred during the 1940s with respect to the 1920s and the 1950s in central Eastern Patagonia (roughly between $45^{\circ}-52^{\circ} \mathrm{S}$ and $72.5^{\circ} \mathrm{W}$-to the eastern coast). Hence, the authors proposed that increased precipitation in the arid and semiarid areas of central Eastern Patagonia during the 1940s could have been induced by the Atlantic's wet air mass advection, which was more frequent than in previous or subsequent decades. This suggestion still remains to be analyzed.

It is true that when exploring the low-level tropospheric circulation over Patagonia, if mean conditions such as monthly or seasonal to yearly conditions are used, it will only yield an average configuration, which confirms the former westerlies rule. Hence, any association between the near surface climate variables and the low-tropospheric circulation in Patagonia is reducibly linked to the strengthening or weakening of the westerlies aloft. The westerlies rule has long been considered in the literature as the unique driver of climate in both Western and Eastern Patagonia, especially in past climate studies. Thus, from the combination of proxy-data and modelling, past environments are reconstructed using the westerlies mechanism. Furthermore, a recent update on the palaeoclimatic southern westerlies variability by Fletcher \& Moreno (2012) concluded that the northerly (southerly) displacement has little, if any, effect on the mean latitudinal position of the westerlies relative to today, dealing with their functioning and impact on the mid-latitude climate 'is still a matter of discussion and consensus remains elusive' (p. 33), and, thus, it 'poses a formidable challenge to an understanding of the modes of climatic variability of the southern extratropics' (p. 1, Abstract). The current palaeoclimatic literature virtually excludes the possible role of winds blowing westward from the South Atlantic.

We will show evidence to support the hypothesis that the westerlies rule is inadequate to satisfactorily derive temporal variations in present climatic variables in central Eastern Patagonia and, ultimately, the interpretation of palaeoclimatic reconstructions. 
We looked at the hypothesis with regard to precipitation that involves synoptic scale perturbations. The westerlies rule is violated especially under quasistationary synoptic easterly moisture flux conditions. To support the hypothesis, we first explored (Section 3.1) the prevalent mean and synoptic-scale tropospheric circulation and moisture conditions during the relatively wet 1940s in central Eastern Patagonia in comparison to other decades, as suggested by Barros \& Mattio (1978). During the 1940s, the areas of wet anomaly involved Lago Cardiel (Fig. 1), a hydrologically closed lake basin that both in the present and the past has been decoupled from glacial or melt-

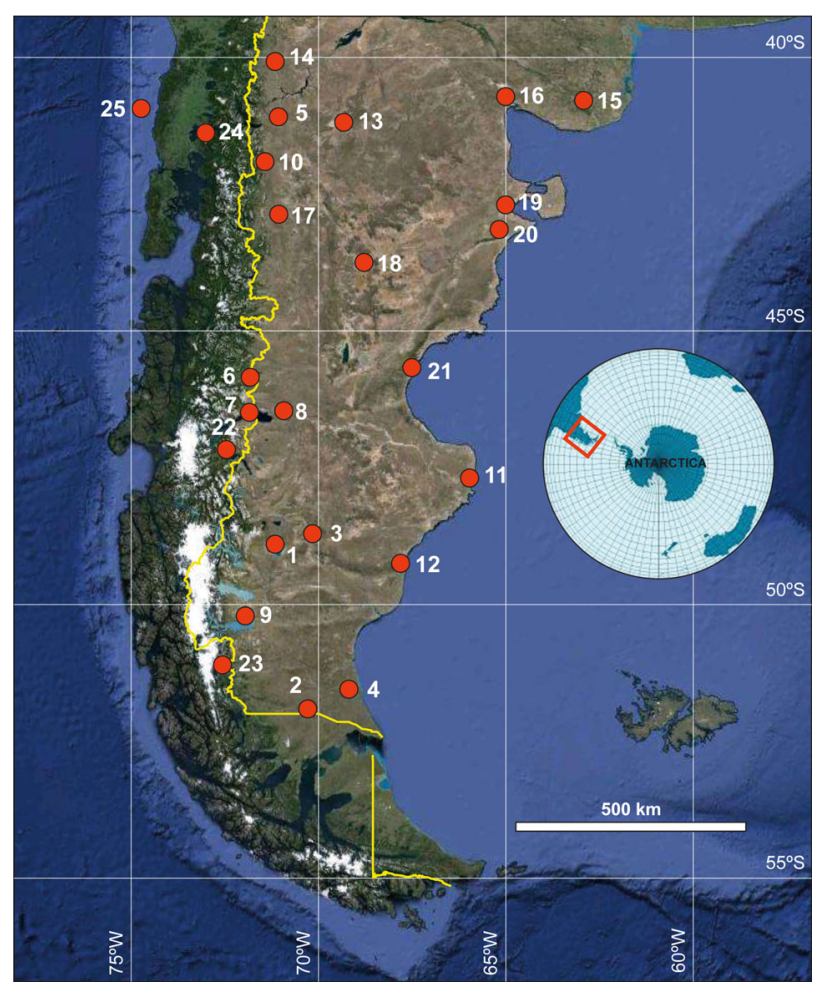

Fig. 1. Southern South America (Google Earth image) with study sites (red dots), and a view of the Southern Hemisphere (inset). The northern (southern) boundary of the red square in the inset view of the southern hemisphere shows the lowest (highest) latitude affected by the Westerlies. Thus, Patagonia is the largest continent affected by the Westerly wind belt. Study sites - (1) Lago Cardiel: $48.96^{\circ} \mathrm{S}, 71.25^{\circ} \mathrm{W}$; (2) Laguna Potrok Aike: $51.97^{\circ} \mathrm{S}, 70.38^{\circ} \mathrm{W}$ (for coordinates of Sites 322, see Table 1); meteorological stations-(3) Gobernador Gregores; (4) Rio Gallegos; (5) San Carlos de Bariloche; (6) Balmaceda; (7) Chile Chico; (8) Perito Moreno; (9) El Calafate (formerly named Lago Argentino); (10) El Bolsón; (11) Puerto Deseado; (12) San Julian; (13) Maquinchao; (14) Chapelco; (15) Viedma; (16) San Antonio Oeste; (17) Esquel; (18) Paso de Indios; (19) Puerto Madryn; (20) Trelew; (21) Comodoro Rivadavia; (22) Lord Cochrane; (23) Lago Guanaco: $51.25^{\circ} \mathrm{S}, 72.25^{\circ} \mathrm{W}$; (24) Lago Condorito: $41.76^{\circ} \mathrm{S}$, $73.12^{\circ} \mathrm{W}$; sediment core-(25) GeoB $3313-1$ : $41^{\circ} \mathrm{S}, 74.45^{\circ} \mathrm{W}$ water input and is mainly influenced by precipitation (Stine \& Stine 1990, Gilli et al. 2001). Within the basin of the Lago Cardiel, there is only one meteorological station available: Gobernador Gregores $\left(48.71^{\circ} \mathrm{S}\right.$, $70.29^{\circ} \mathrm{W}$ ). We also analysed (Section 3.2) the statistical relationship between daily precipitation and zonal moisture transport using both data from stations close to the lake and reanalysis of historical data.

Likewise, proxy data from combined seismic, sedimentological and geochemical investigations of the lake basin have provided the first record of lake-level changes from the Late Glacial to the Holocene (Gilli et al. 2001, 2005, Markgraf et al. 2003); thus, we were able to make inferences from present climate to past climate. Unfortunately, there were no measurements of present lake level variations other than current mean lake level, which is $76 \mathrm{~m}$ of depth (Gilli et al. 2001). In order to illustrate how weather conditions of quasi-stationary easterlies influence daily precipitation, the heavy rain spell that occurred at the lake area during the austral late summer 2002 was examined (Section 3.3). Finally, we further discuss (Section 3.4) these present climate observations in the context of previous results for past climate, based on proxies and the most relevant Mid-Holocene general circulation model (GCM) scenarios provided by Wagner et al. (2007), Rojas \& Moreno (2011) and Pollock \& Bush (2013), to elucidate the palaeoclimate conditions over Patagonia that were involved in the high water levels of Lago Cardiel recorded during the early (9000-10000 calibrated [cal] yr BP) and mid- (6000 cal yr BP) Holocene.

\section{DATA AND METHODOLOGY}

Patagonia is a vast geographical expanse with a relatively low number of meteorological stations. Most are located on the Pacific and Atlantic coasts, while the interior lands are poorly represented. We chose 20 weather stations (Fig. 1, Table 1) to describe (see Section 3.3) the synoptic meteorological conditions of a heavy rainfall event that occurred in March 2002 in the area of Lago Cardiel (site no. 1, Fig. 1). We used daily accumulated precipitation ( $\mathrm{P}$ in $\mathrm{mm}$ ), sub-daily data of $10 \mathrm{~m}$ vector winds and wind gusts $\left(\mathbf{V}_{10}\right.$ in $\left.\mathrm{km} \mathrm{h}^{-1}\right)$, provided by the 'Servicio Meteorológico Nacional' (the Argentine Weather Service, www.smn.gov.ar/) and by the 'Dirección Meteorológica de Chile' (the Chilean Weather Service, www.meteochile.gob.cl). The weather synopsis was complemented with sub-daily (6-hourly) atmospheric data from the European Centre for Medium-Range 
Weather Forecasts (ECMWF) Interim Re-Analysis (ERA-interim) provided on a regular $0.75^{\circ}$ latitudelongitude grid with 37 model levels (retrieved from www.ecmwf.int). ERA-Interim is the latest of the ECMWF reanalysis covering the post-1979 period (Berrisford et al. 2011a). ERA-Interim is based on an atmospheric model and reanalysis system with 60 vertical levels and a top level at $0.1 \mathrm{mb}$, a T255 spherical harmonic representation and a reduced Gaussian grid with about $79 \mathrm{~km}$ spacing for surface and gridpoint fields (Berrisfordet al. 2011b). The atmospheric data consisted of analysis variables (step $=0$ ) of sea level pressure (SLP, in $\mathrm{hPa}$ ), surface winds $\left(\mathbf{V}_{\mathrm{s}}\right.$ in $\left.\mathrm{m} \mathrm{s}^{-1}\right), 850 \mathrm{hPa}$ specific humidity $\left(\mathrm{Q}\right.$, in $\left.\mathrm{g} \mathrm{kg}^{-1}\right)$, $300 \mathrm{hPa}, 500 \mathrm{hPa}$ and $850 \mathrm{hPa}$ geopotential (GP, in $\mathrm{m}^{2}$ $\left.\mathrm{s}^{-2}\right)$ and $300 \mathrm{hPa}$ and $850 \mathrm{hPa}$ vector wind $\left(\mathbf{V}\right.$, in $\left.\mathrm{ms}^{-1}\right)$ at the 4 synoptical hours 00Z, 06Z, 12Z and 18Z at Greenwich. Daily variables were estimated as the average of available synoptic hours. ERA-Interim total precipitation (TP, in $\mathrm{m}$ ) was derived at $00 \mathrm{Z}$ and $12 \mathrm{Z}$ after $12 \mathrm{~h}$ of integration (step =12). Daily accumulated TP was estimated as the sum of the 2 synoptic hours.

A daily blocking index devised by Tibaldi \& Molteni (1990), known as the TM index and updated for the Southern Hemisphere by Mendes et al. (2008), was applied to ERA-Interim $500 \mathrm{hPa}$ daily geopotential height (GPH) at $90^{\circ}$ and $60^{\circ} \mathrm{W}$ in order to estimate the blocking action of specific days. Therefore, two $500 \mathrm{hPa}$ GPH meridional gradients GHGS (south) and GHGN (north) were evaluated: GHGS $=\mathrm{GPH}\left(75^{\circ} \mathrm{S}\right)-$ $\mathrm{GPH}\left(65^{\circ} \mathrm{S}\right)$ and $\mathrm{GHGN}=\mathrm{GPH}\left(65^{\circ} \mathrm{S}\right)-\mathrm{GPH}\left(50^{\circ} \mathrm{S}\right)$. The criterion to determine a blocking action day at a given longitude was GHGN $>0$ and GHGS $<-10 \mathrm{~m}$.

In addition, the ERA-Interim data archive provided the analysis (step $=0$ ) of zonal and meridional components of vertically integrated moisture flux (VIMF, in $\mathrm{kg} \mathrm{m}^{-1} \mathrm{~s}^{-1}$ ) at 4 canonical synoptic hours, offering information about moisture transport. In the middleto-high latitudes, moisture transport is mainly carried out by the zonal component of the flux (Trenberth \& Guillemot 1998). Values of zonal VIMF $>0$ indicate eastward moisture transport and values of zonal VIMF $<0$ suggest westward moisture transport. Inasmuch as our concern was to characterise the moisture flux in the area of Lago Cardiel in central Eastern Patagonia, eastward (westward) zonal VIMF was accordingly related to Pacific (Atlantic) moisture sources. This information was used for the weather synopsis described in Section 3.3 as well as for establishing the link between daily precipitation and zonal moisture transport.

The latter connection was examined using daily information for the variables during 1979 to 2013 (total number of days, $\mathrm{N}=12784$ ). We picked out the Gobernador Gregores station, which was the only weather station inside the catchment area of Lago Cardiel, and the closest meteorological stations with long and reliable records, namely, San Julian, Puerto Deseado, Paso de Indios, Comodoro Rivadavia and El Calafate. Thus, daily accumulated precipitation at each station was classified into 7 class intervals according to its magnitude: without precipitation (no $\mathrm{P}), \mathrm{P}=0 \mathrm{~mm}$ (traces), $0 \mathrm{~mm}<\mathrm{P}<1 \mathrm{~mm}$ (very weak precipitation), $1 \mathrm{~mm} \leq \mathrm{P}<5 \mathrm{~mm}$ (weak precipitation), $5 \mathrm{~mm} \leq \mathrm{P}<10 \mathrm{~mm}$ (moderate precipitation) and $10 \mathrm{~mm} \leq \mathrm{P}$ (intense precipitation). For each class interval, the total number of days with either westward or eastward VIMF was counted in order to establish any statistical relationship between daily precipitation magnitude and the zonal moisture transport. The local zonal moisture transport was estimated as the spatial average of VIMF over gridpoints centred at the site of every station on a $2^{\circ}$ latitude-longitude box. Additionally, for the $2 \mathrm{~d}$ of highest daily precipitation on record at Gobernador Gregores, the zonal moisture transport fields and mass trajectories were estimated. The latter were calculated in order to visualize the approximated path travelled by the air mass that produced the precipitation. Mass trajectories were computed using the code kindly supplied by the University of Melbourne and implemented at the website of NOAA-ESRL Physical Sciences Division, Boulder Colorado (at www.esrl. noaa.gov/psd/). Moreover, in order to characterise the main synoptic atmospheric circulation features associated with intense precipitation $(\mathrm{P} \geq 10 \mathrm{~mm})$ measured at Gobernador Gregores under strong westward or eastward moisture transport, daily field composites of SLP, $850 \mathrm{hPa} \mathbf{V}$ and TP were estimated for the $20 \mathrm{~d}$ in this category with the lowest negative and positive values of local zonal VIMF estimated at the station site. The composite of daily anomaly of a given variable was estimated as follows: the climatological (1981-2010) monthly mean was subtracted from daily fields to obtain daily anomalies comparable through the annual cycle, thus every anomaly field was combined into a composite field.

The moist 1940s in central Eastern Patagonia were examined using nearly century-long, interpolated gridded datasets, which are extensively used in climate studies seeking to find spatial patterns of variability (Garreaud et al. 2009). These gridded datasets are derived from a few stations in the Southern Hemisphere (SH) at mid-to-high latitudes, which weakens their accuracy of representing actual local climatic conditions. In order to obtain a more robust, 
qualitative evaluation of spatial precipitation anomalies over the region, we used 2 historical gridded interpolated monthly precipitation datasets at high resolution $\left(0.5^{\circ} \times 0.5^{\circ}\right.$ lat-lon $)$. One was produced by the Climatic Research Unit CRU: precipitation data version 3.21 from 1901-2010 (retrieved from https:// climatedataguide.ucar.edu/climate-data/cru-ts321gridded-precipitation-and-other-meteorologicalvariables-1901). The other dataset was produced by the Center for Climatic Research, University of Delaware (UDel): precipitation data version 3.01 from 1900-2010, provided by the NOAA/OAR/ESRL PSD, Boulder, Colorado (from their website at www. esrl.noaa.gov/psd). Another historical dataset available was produced by the Global Precipitation Climatology Centre (GPCC), which we decided to exclude because it presented a bias in representing precipitation in Eastern Patagonia. The interpolation scheme tended to make the high precipitation amounts of Western Patagonia propagate into Eastern Patagonia, a bias that has also been suggested by Schneider et al. (2014).

The unusual seasonal precipitation during the 1940s were described as the decadal difference of the 1940s precipitation field minus the 1950s precipitation field for each season. The difference between precipitation fields of the 1940s and 1920s were assessed in a similar manner. The decadal precipitation difference anomalies were tested using the unequal-variance Student's $t$-test, evaluated at 3 significance levels for $\alpha$ : $0.1,0.05$ and 0.01 (Moser \& Stevens 1992). Likewise, decadal difference anomalies for some atmospheric variables from the 20th Century Reanalysis V2 data (20CR) were estimated in order to analyse the relevant features of the seasonal low-level tropospheric circulation during the 1940s. The 20CR was provided by the NOAA/OAR/ ESRL PSD on a $2^{\circ}$ latitude $\times 2^{\circ}$ longitude global grid (retrieved from www.esrl.noaa.gov/psd/). The examined monthly atmospheric fields were GPH (in m) and $\mathbf{V}$ (in $\mathrm{m} \mathrm{s}^{-1}$ ) at $1000 \mathrm{hPa}$, as well as low-to-midtroposphere daily zonal wind $\left(\mathrm{U}\right.$, in $\left.\mathrm{m} \mathrm{s}^{-1}\right)$ and specific humidity $\left(\mathrm{Q}, \mathrm{g} \mathrm{kg}^{-1}\right)$. We approximated the daily zonal VIMF in the layer 1000-500 $\mathrm{hPa}$ using the fields of $U$ and $Q$, following the vertically integrated moisture equation and integration scheme suggested by Trenberth (1991). The decadal average of number of days with westward moisture transport (zonal VIMF < 0) and with low level easterlies $(1000 \mathrm{hPa} \mathrm{U}<$ 0 ) were estimated for the 4 seasons in each decade. The decadal difference anomalies were tested and expressed as a percentage of days with westward flow per season.

\section{RESULTS AND DISCUSSION}

\subsection{Precipitation during the 1940 s in central Eastern Patagonia}

According to Barros \& Mattio (1978), the 1940s were significantly wetter than the previous and following decades in central Eastern Patagonia, contributing to a progressive desertification. The seasonal precipitation mean was averaged over the periods 1941-1950, 1951-1960 and 1921-1930 for each season using the UDel and CRU datasets. The difference of the 1940s with respect to the other 2 decades (1941-1950 minus 1951-1960, and 1941-1950 minus 1921-1930) for both datasets qualitatively showed a similar spatial pattern of decadal anomalies. Since some meteorological stations within the region started to operate around the end of the 1920s or the beginning of the 1930s, only the decadal difference of the 1940s minus the 1950s were shown and discussed because the interpolated gridded data were more reliable. During austral fall (MAM) and spring (SON), the decadal difference anomalies were positive and significant, whereas during summer (DJF) and winter (JJA), they were negative (figures not shown). Note that, in central Eastern Patagonia, the climatological annual cycle showed a relative maximum during fall that decreased towards summer (Prohaska 1976, Hoffmann 1992, Aravena \& Luckman 2009). Therefore, the statistically significant relative increase in precipitation during the 1940s occurred only during the transitional seasons, shown in Fig. 2. The 1940s positive precipitation anomalies over central Eastern Patagonia, where Lago Cardiel is located, were qualitatively consistent between CRU and UDel for both MAM (Fig. 2a,b) and SON (Fig. 2d,e). The CRU anomalies showed more spatially extended significant positive anomalies (green shadow areas) and insinuated a west-east precipitation dipole between wet central Eastern Patagonia (east) and dry central Western Patagonia (west). The increased fall and spring precipitation during the 1940s over the area could be associated with an increased percentage of days with zonal moisture transport from the east (zonal VIMF < 0), extending over most of southern South America and the South Atlantic (Fig. 2c,f). For both MAM and SON, there were significantly more days with westward moisture transport around Eastern Patagonia in the 1940s relative to the 1950s, resulting in a meaningful physical structure of moisture transport from the Atlantic basin toward the region. 

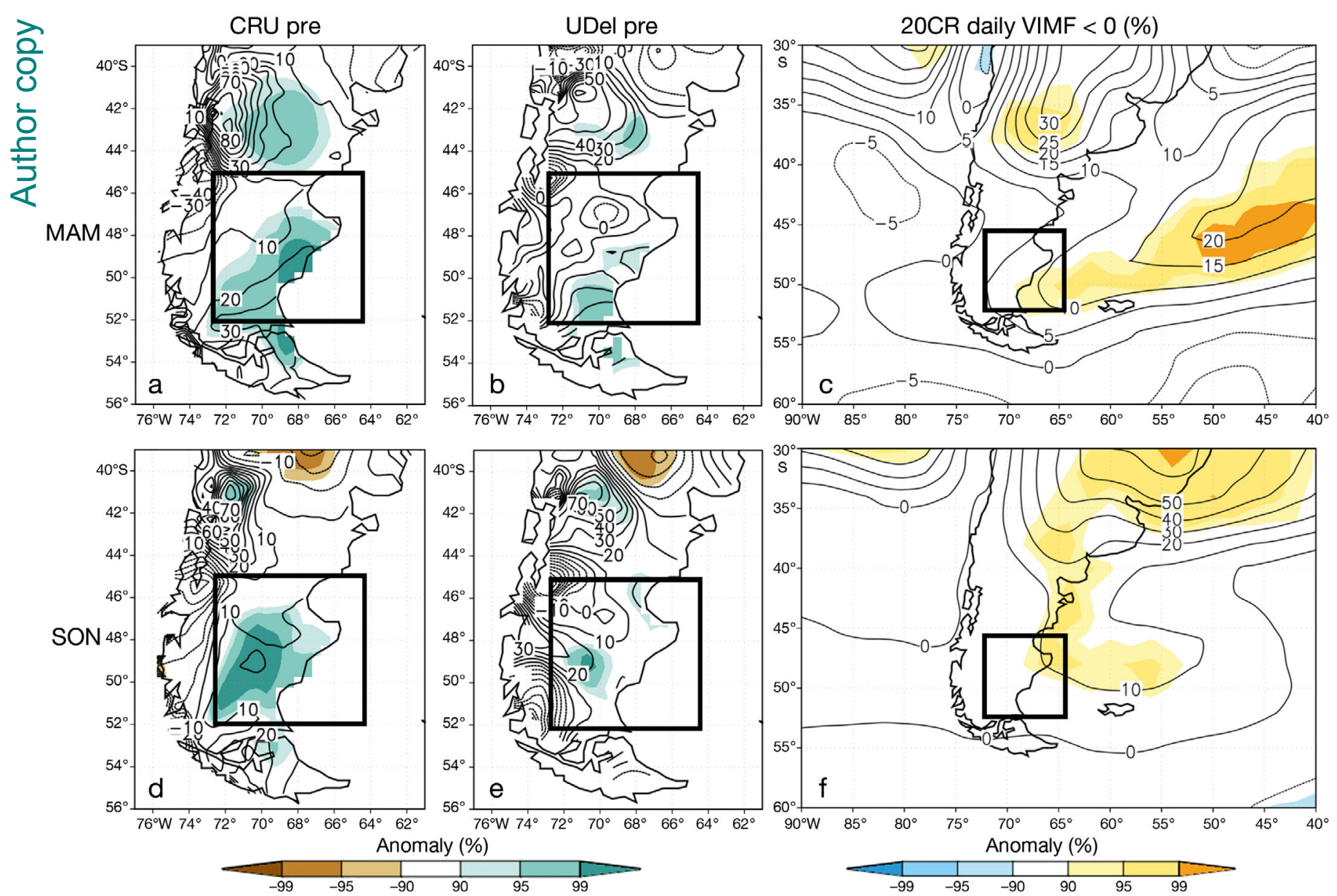

Fig. 2. Decadal anomalies of the 1940s versus the 1950s: (a,b,d,e) contours show seasonal precipitation (pre, in mm) from (a,d) CRU dataset, (b,e) from UDel dataset; and (c,f) contours show daily westward moisture transport (vertically integrated moisture flux $[$ VIMF] < 0) in percentage (\%) per season from the 20CR dataset. Top: fall month (MAM); bottom: spring month (SON). Color bars: color shades denote negative to positive anomalies at the 90, 95 and $99 \%$ confidence levels, using an unequal variance Student's $t$-test. Rectangle: rough location of central Eastern Patagonia

The low level tropospheric circulation associated with the 1940s positive precipitation anomalies are shown in Fig. 3 for fall and spring. Anomalies were described by the 20CR geopotential height (Fig. 3e) and vector wind (Fig. 3f) at $1000 \mathrm{hPa}$ together with the anomalous percentage of days with $1000 \mathrm{hPa}$ westward zonal wind $(U<0)$, all of them estimated as the difference between the decadal average over the 1940s and 1950s. The overall picture of decadal mass flow anomalies depicted an anticyclonic low-level atmospheric circulation over the mid-to-high latitudes encompassing the Pacific, Atlantic and Southern Oceans for both MAM and SON (Fig. 3a,e). The decadal $1000 \mathrm{hPa}$ vector wind anomalies pointed westwards most often over the Atlantic and Southern Oceans in SON, and also over the Pacific in MAM (Fig. 3b,f). The latter established a significant reduc- tion of the mean mid-latitude low-level westerlies affecting central Eastern Patagonia. The decadal anomaly configurations suggest 2 potential mechanisms that act on precipitation on a daily scale. On one hand, a reduction in the daily intensity of the westerlies lead to less accentuated mechanical effects of the Andes (subsidence) and more precipitation in Eastern Patagonia, suggested by Garreaud et al. (2013) as a possible explanation of the indirect correlation that they obtained between precipitation and low level winds. The significantly weakened daily westerlies ( $U>0$ ) observed over mid-to-high latitudes during the transitional seasons (Fig. 3d,h) were in overall agreement with this assertion. On the other hand, an increase in the number of days with easterlies $(U<0)$ at mid-to-high latitudes brought moist air masses from the Atlantic. Accordingly, 

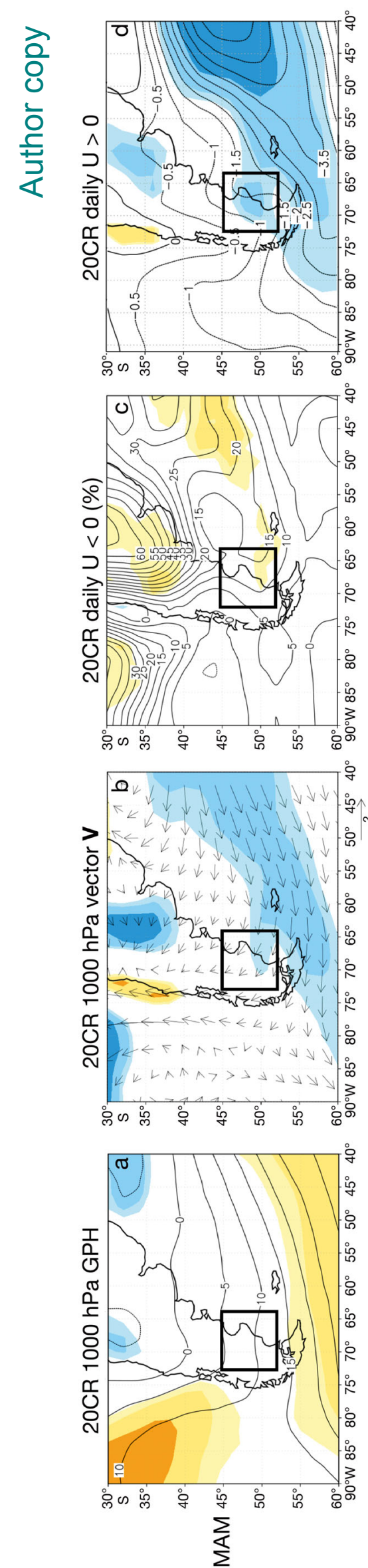
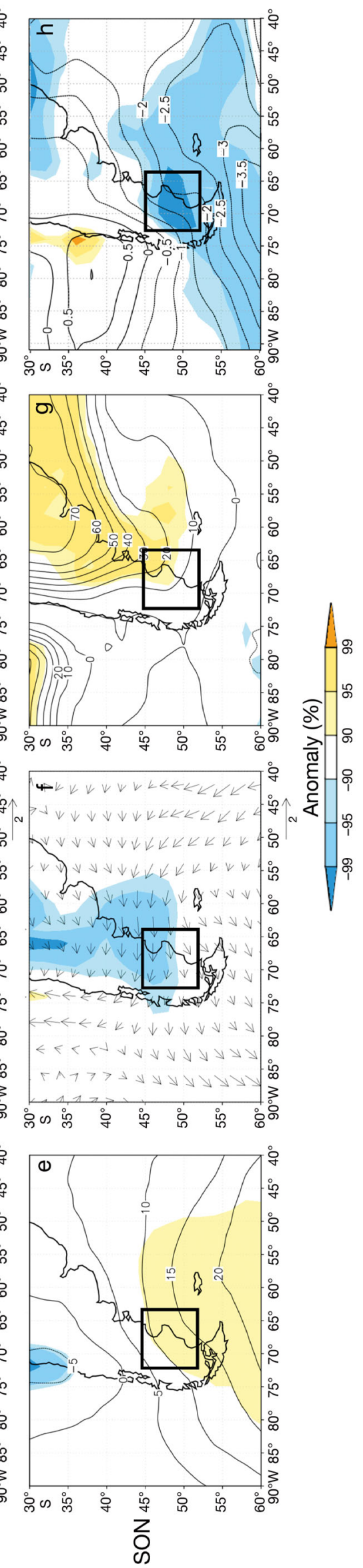

\begin{abstract}
\& $\cong$ Fig. 3c,g shows that the number of 要 days with easterlies on a daily scale in $\&$ was significantly increased over a most of the mid-latitude Atlantic

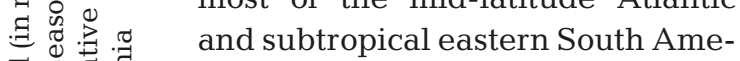
要 范 空

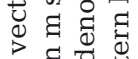

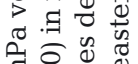
विष 造远㐘

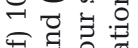
उ 380

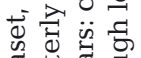

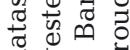

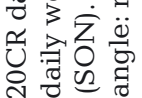

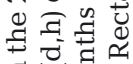
: 政 द्व 政放 露过 원료

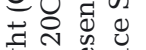

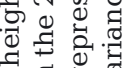
굴

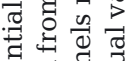
ญ

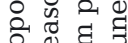
is क्षे 흥 व

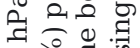

rica during the fall and spring of the 1940s. Similar results were obtained for other lower levels (below $700 \mathrm{hPa}$; figures not shown), which was consistent with a daily net moisture transport from the Atlantic (Fig. 2c,f).

In consequence, the precipitation increment recorded in central Eastern Patagonia during fall and spring of the 1940s, with respect to the 1950 s, was linked to an anomalous anticyclonic low-level tropospheric circulation that provided weaker daily westerlies (less accentuated subsidence) and enhanced air-mass flow from the Atlantic with a net westward synoptic moisture transport over the Lago Cardiel catchment area and its surroundings. The nature of the link between precipitation and zonal moisture transport in the region could be examined in detail by analysing daily information from a more robust reanalysis dataset and over a period longer than a decade.
\end{abstract}

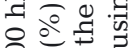
\& 8

os

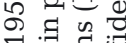

o 0 证 os 2 द 包 s.

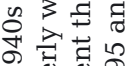
S뭉 屯

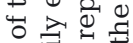

की

表

वृ कृ :

更

శี

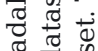

$\pi \frac{\pi}{8}$

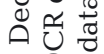

mi

क्षे

\subsection{Daily precipitation linked to zonal moisture transport}

Since daily moisture transport data derived from ERA-Interim were available from 1979, the study of the long-term climatology of the daily precipitation/moisture link was performed from 1 January 1979 to 31 December 2013. The daily precipitation data were from the meteorological station of Gobernador Gregores, inside the Lago Cardiel catchment basin. The plains in central Eastern Patagonia are characterised by arid conditions. The Gobernador Gregores weather station reports on average $140.5 \mathrm{~mm}$ of precipitation annually. 
In addition, the stations of San Julian, Puerto Deseado, Comodoro Rivadavia, Paso de Indios and El Calafate were included in order to make results more robust. The stations are the closest ones to Gobernador Gregores and have the best available record quality, and are located inside the significant wet areas observed during the 1940s.

Daily accumulated precipitation was stratified into class intervals according to its magnitude at every station. The number of days within each interval was split according to the net local westward or eastward moisture transport, determined by the sign of the local zonal VIMF. Given that the stations are located in the same latitude band as the westerlies, the number of days with local westward (negative) VIMF was considerably lower than the number of days with local eastward (positive) VIMF at all stations. This is the reason why the climatological moisture flux is eastward in mid-to-high latitudes over southern South America (Trenberth \& Guillemot 1998). The average among the meteorological stations barely yielded $\sim 4 \%$ of days with local westward moisture transport during the baseline 1979-2013. However, when the event was discriminated according to the magnitude of precipitation, a remarkable result was obtained. For the days without precipitation (no P), which is on average $\sim 80 \%$ of the total number of days, the percentage of days with local westward moisture transport decreased to $\sim 2 \%$, i.e. more than a half lower than for the total number of days of westward moisture flux occurrence. The latter reduction suggests that the likelihood of joint occurrence of daily westward moisture transport and precipitation was not random. In other words, albeit westward moisture flux was not frequent, more than $60 \%$ of the time when it happened, it rained. Ergo, there was a favourable propensity of increased precipitation under westward moisture transport. In contrast, the probability of days with local zonal moisture transport towards the east without precipitation (no P) was higher than $98 \%$. In turn, the diagrams of daily frequency of local westward (Atlantic) moisture transport (zonal VIMF $<0$ ), relative to the total number of cases included in each class interval of precipitation magnitude, showed a similar shape among stations (Fig. 4). It was observed that the percentage of days with westward (eastward) moisture transport increased (decreased) through class intervals of increasing precipitation magnitude. Therefore, the more (less) frequently that local westward (eastward) moisture transport events occurred, the higher (lower) was the intensity of daily precipitation. The rate of change indicated a non-linear link between the variables. The result is clear evidence that strong rainfalls are related to an additional Atlantic moisture source. The relative maximum of daily percentage of westward moisture transport is aligned with intense precipitation $(\mathrm{P} \geq 10 \mathrm{~mm})$ at all stations, ranging
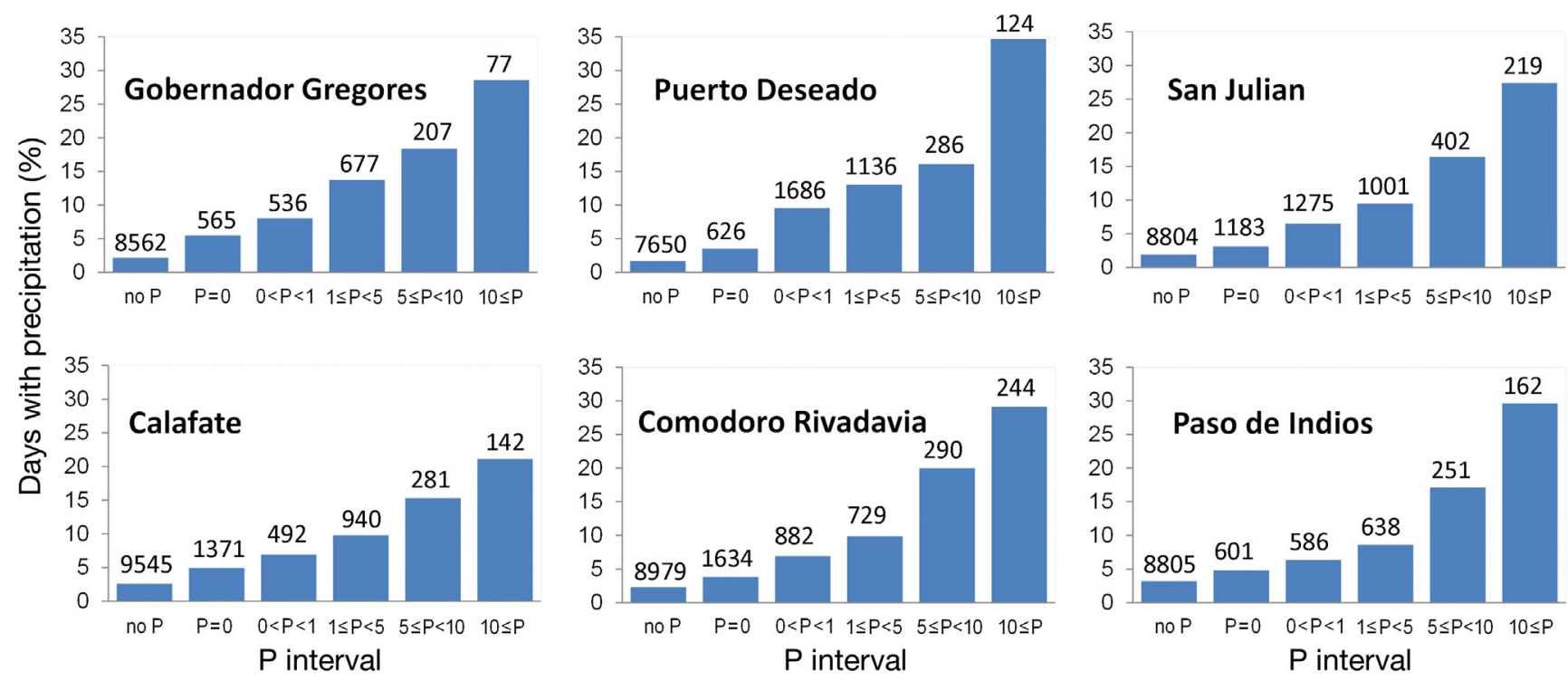

Fig. 4. Days with precipitation $(\mathrm{P})$ in the class interval: no $\mathrm{P}$ (without precipitation), $\mathrm{P}=0 \mathrm{~mm}$ (traces), $0 \mathrm{~mm}<\mathrm{P}<1 \mathrm{~mm}$ (very weak precipitation), $1 \mathrm{~mm} \leq \mathrm{P}<5 \mathrm{~mm}$ (weak precipitation), $5 \mathrm{~mm} \leq \mathrm{P}<10 \mathrm{~mm}$ (moderate precipitation) and $10 \mathrm{~mm} \leq \mathrm{P}$ (intense precipitation), accumulated during days with local westward moisture transport at Gobernador Gregores, Puerto Deseado, San Julian, Calafate, Comodoro Rivadavia and Paso de Indios; expressed in percentage with respect to the total number of days within each class interval (numbers above bars), from 1 January 1979 to 31 December 2013 
between $21 \%$ of the total number of days in that class interval $(\mathrm{n}=142)$ at El Calafate and $35 \%(\mathrm{n}=124)$ at Puerto Deseado. Note that the 2 stations are located at the westernmost and easternmost boundaries of the region, respectively; in consequence, the probability of daily intense precipitation with moisture transport from the east decreases westward. The latter further supports the assumption that the Atlantic is an additional source of moisture at least during intense precipitation events. The Gobernador Gregores station is located in the middle of the region, inside the Lago Cardiel catchment basin, and showed intermediate values compared to the others.

In particular, the $2 \mathrm{~d}$ with the highest precipitation according to the Gobernador Gregores' records were 25 June 2000 ( $\mathrm{P}=37 \mathrm{~mm}, 26 \%$ of the annual $\mathrm{TP})$ with net local moisture transport towards the west (local zonal VIMF $=-54.3 \mathrm{~kg} \mathrm{~m}^{-1} \mathrm{~s}^{-1}$ ) and 20 April 1998 ( $\mathrm{P}=32 \mathrm{~mm}$, a $23 \%$ of annual TP) with net local moisture transport toward the east (local zonal VIMF = $+161.7 \mathrm{~kg} \mathrm{~m}^{-1} \mathrm{~s}^{-1}$ ). The remaining stations also recorded precipitation on those dates with congruent local zonal VMIF values. Fig. 5 shows the daily field of zonal moisture transport (Fig. 5a,b) and the $4 \mathrm{~d}$ backward trajectories of air mass arriving at the Lago Cardiel catchment area (Fig. 5c,d) for both dates. The 20 April case represents typical precipitation in central Eastern Patagonia related to eastward moisture transport (Fig. 5a) together with an accordingly approximated air mass trajectory from the Pacific at lower levels (Fig. 5c). Typically, synoptic precipitation is frequently connected with moist westerly winds (Garreaud et al. 2013) together with an incoming trough from the South Pacific (Barrett et al. 2011). In contrast, the 25 June case showed a wide mid-latitude band with zonal negative VIMF that indicated an air-mass flow from the Atlantic (Fig. 5b). Accordingly, the lower level mass trajectory was entirely over the southwestern South Atlantic for almost $4 \mathrm{~d}$ before arriving at Lago Cardiel (Fig. 5d). The persistence of air masses moving westward, as indicated by the trajectory, could be related to synoptic-scale quasi-stationary flow linked to high latitude blocking highs (Berbery \& Nuñez 1989). The synoptic weather
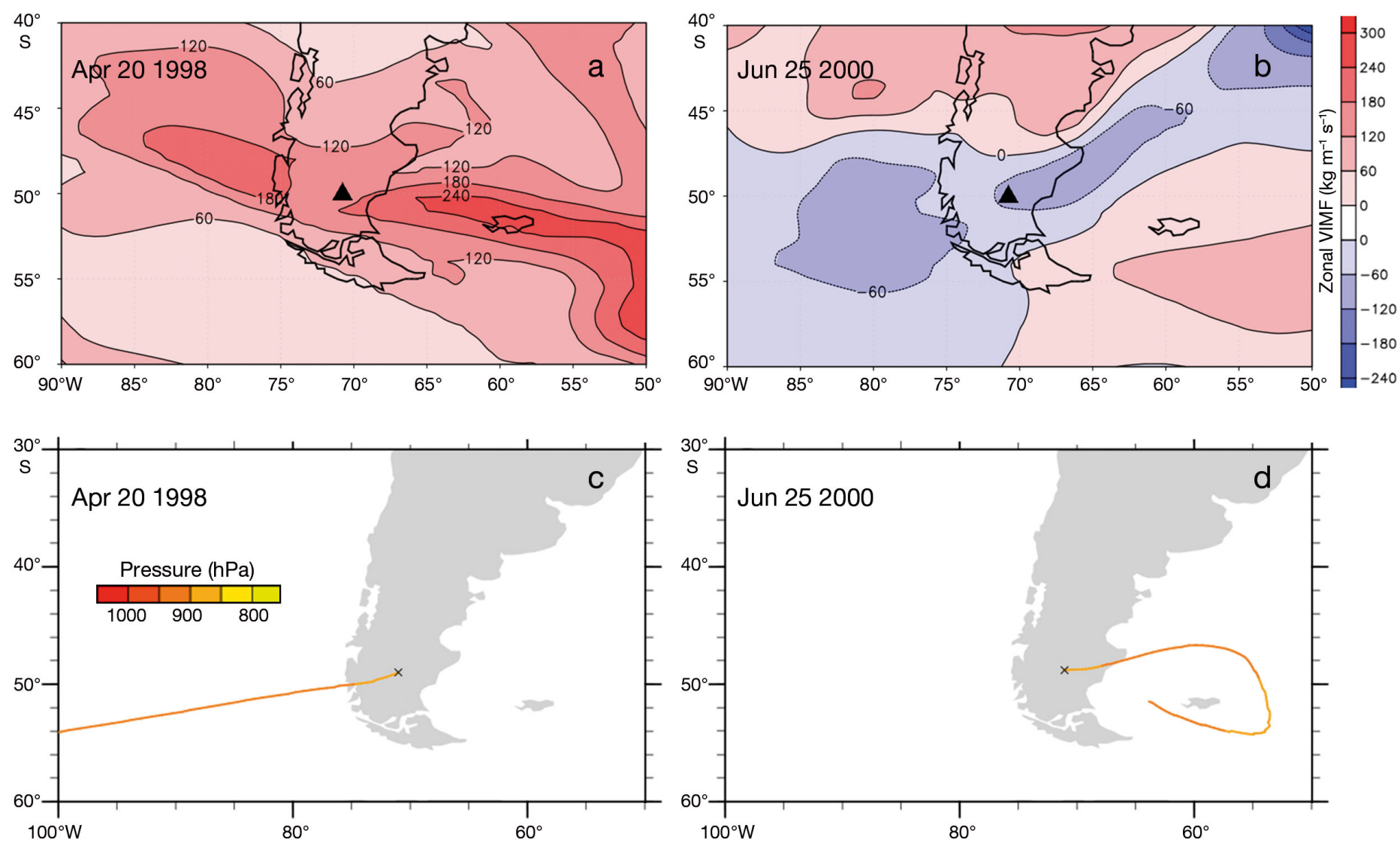

Fig. 5. Zonal moisture transport (zonal VIMF) for the $2 \mathrm{~d}$ with highest daily accumulated precipitation at Gobernador Gregores, (a) 20 April 1998; (b) 25 June 2000; (c,d) trajectory of the $925 \mathrm{hPa}$ air mass (and standard pressure levels, indicating the level of the air mass in its trajectory) during the $4 \mathrm{~d}$ prior to its arrival at the Lago Cardiel area (cross mark, latitude $=49^{\circ} \mathrm{S}$, longitude $=71^{\circ} \mathrm{W}$ ) on the day given. Triangle: Gobernador Gregores location 
maps (not shown) revealed a mid-to-high latitude dipole of low-to-high pressure centres over southeastern South Pacific at about $80^{\circ} \mathrm{W}$, which provided blocking conditions for the westerlies. The TM blocking index at $80^{\circ} \mathrm{W}$ indicated a blocking episode lasting $9 \mathrm{~d}$, from 21 to 30 June, over southeastern South Pacific. The blocking-like flow continued later on over the southwestern South Atlantic, for which the blocking index at $60^{\circ} \mathrm{W}$ indicated blocking action between 29 June and 2 July. The precipitation recorded at Gobernador Gregores was also intense on 24 June and moderate on 26 and 27 June, days where lowpressure troughs dominated the upper troposphere over central Eastern Patagonia.

Note that Alessandro (2014) related blocking action in southern South America to increased precipitation in Eastern Patagonia. The use of the TM's blocking index allowed us to count blocking action days over the oceans, to the west and east of Patagonia, associated with intense precipitation at Gobernador Gregores. Noticeably, blocking-like flows at $80^{\circ} \mathrm{W}$ accounted for about $30 \%$ of the days with $\mathrm{P}$ $\geq 10 \mathrm{~mm}$, and blocking-like flows at $60^{\circ} \mathrm{W}$ explained about $12 \%$ of the days. The joint occurrence of blocking action at both $80^{\circ} \mathrm{W}$ and $60^{\circ} \mathrm{W}$ was nearly $2 \%$ of the days. Therefore, about $40 \%$ of the days with blocking-like flow in the vicinity of Patagonia could account for intense precipitation. Furthermore, if days with only zonal westward moisture transport were considered along with intense precipitation, then $\sim 70 \%$ of blocking action days in the region were associated with intense precipitation. Hence, a great fraction of intense precipitation could be ascribed to blocking-like flows inducing enhanced westerly moisture flux from the Atlantic.

To assess the mean differential features of synoptic tropospheric circulation associated with events of intense precipitation at Gobernador Gregores under the influence of intense net zonal moisture transport both westward and eastward, the composite anomalies of daily fields of SLP, $850 \mathrm{hPa} \mathbf{V}$ and TP from ERA-Interim reanalysis were estimated for those $20 \mathrm{~d}$ with the highest and lowest daily values of local zonal VIMF. Fig. 6a shows the composite of the daily precipitation anomalies related to intense westward moisture transport at Gobernador Gregores. Such influence of local net zonal moisture transport from the Atlantic was further highlighted by the negative composite anomalies of daily zonal VIMF (blue shades) over central Eastern Patagonia (Fig. 6b). The Atlantic source of moisture was demonstrated by the zonal dipole of precipitation anomalies established between east and west of Patagonia. Thus, positive precipitation anomalies $>30 \mathrm{~mm} \mathrm{~d}^{-1}$ predominated over central Eastern Patagonia, whereas negative ones $<-30 \mathrm{~mm} \mathrm{~d}^{-1}$ dominated in central Western Patagonia, downstream of the moist air-mass flow blowing from the east. These values of daily precipitation anomaly represented about 50 to $60 \%$ of the reanalysis climatological monthly precipitation for semiarid Eastern Patagonia, and $<10 \%$ for Western Patagonia. Likewise, a north-south precipitation gradient could be distinguished between a drier southern Patagonia and a wetter central Eastern Patagonia. Moreover, the low-level easterly wind anomalies, extended between $100^{\circ}$ and $60^{\circ} \mathrm{W}$, were induced by a meridional dipole of SLP anomalies at $75^{\circ} \mathrm{W}$, whose positive centre was located at about $65^{\circ} \mathrm{S}$ and the negative one at $42^{\circ} \mathrm{S}$. The north-south dipole structure was also prominent in upper tropospheric levels (not shown). Such structure yields an equivalent barotropic anticyclonic anomalous blocking-like flow in place of the mid-latitude westerlies. In shape, it was similar to the one corresponding to the synoptic case previously described for late June 2000.

On the other hand, intense precipitation and westward moisture flux at Gobernador Gregores resulted in northwesterly air-mass flow over the southeastern South Pacific near the Andes, which was linked to an anomalous cyclonic centre located at about $45^{\circ}$ to $50^{\circ} \mathrm{S}$ (Fig. 6d). The synoptic configuration was similar to that of migratory weather systems with an anomalous anticyclonic centre displaced south-westward from the anomalous cyclonic centre. At southern latitudes over the South Atlantic, an anomalous ridge of positive SLP was also observed. The source of moisture was substantiated once more with the spatial distribution of precipitation anomalies. This time, the main positive anomalies were located in central Western Patagonia, west of the Andes over the Chilean coast, and extended to the east over a part of central Eastern Patagonia depicting lower magnitudes (Fig. 6c). The latter is indicative of a Pacific source of moisture.

So far, our findings show that precipitation in central Eastern Patagonia can occur under both westward and eastward moisture flux, with a higher propensity under westerly flux. The Atlantic Ocean appears to be an additional source of moisture during intense precipitation events, in part as a result of slow-moving weather systems providing blockinglike flows in the region. To our knowledge, a synoptic sequence of weather conditions corresponding to moisture transport from the east over central Eastern Patagonia has not yet been described in the literature. Therefore, in the following section, the weather 

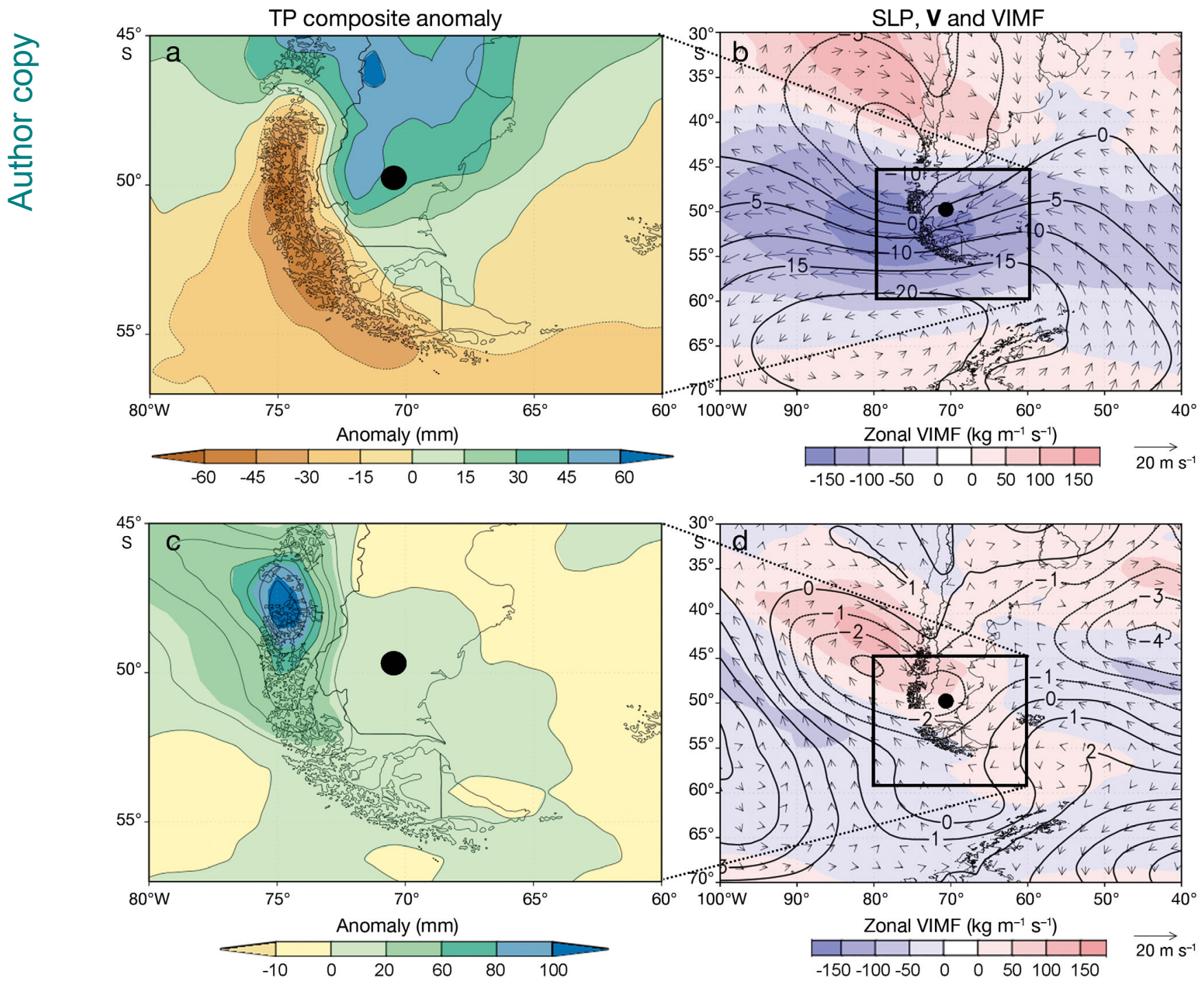

Fig. 6. Daily composite anomalies with respect to the climatology for 1981-2010 for those $20 \mathrm{~d}$ with intense precipitation and strong local westward moisture transport (VIMF < 0) at Gobernador Gregores for (a) ERA-Interim total precipitation (TP); (b) sea level pressure (SLP, contours every $5 \mathrm{hPa}$ ), ERA-Interim $850 \mathrm{hPa}$ vector wind (arrows) and zonal moisture transport given by the ERA-Interim zonal VIMF; (c) and (d), the same as for (a) and (b), but for those $20 \mathrm{~d}$ with intense precipitation and strong local eastward moisture transport (VIMF > 0) at Gobernador Gregores. Black dot indicates the Lago Cardiel location

synopsis related to an extraordinarily heavy rainfall event at the Lago Cardiel catchment area that occurred in March 2002 will illustrate the case.

\subsection{Heavy rainfalls during March 2002 and blocking-like flow}

A heavy rain spell occurred in March 2002 during the austral summer, when the Aiztegui's research team was performing fieldwork in Lago Cardiel. During this event, the lake catchment underwent intense precipitation to such an extent that the team had to be rescued by helicopter by the local rescue service. Such extraordinary phenomena are well known by the locals. People usually describe it using a popular phrase 'Easterly winds bring a plague of rain', which was in fact the headline of the local newspaper during that period.

Between the 12th and the 21st March 2002 (henceforth, dates in March given as ordinal numbers), 2 episodes of intense precipitation $(P \geq 10 \mathrm{~mm})$ were recorded at the Gobernador Gregores station (Table 1), in the vicinity of Lago Cardiel. The first episode occurred on the 13th and 14th when Ariztegui's team was rescued, and the second one occurred 
on the 18th. Gobernador Gregores recorded an extraordinary $63 \mathrm{~mm}$ of precipitation due to the intense weather event on the 13th, 14th and 18th, representing $\sim 48 \%$ of the annual total rainfall and over $500 \%$ of the climatological monthly mean of March precipitation. Other stations in central Eastern Patagonia that simultaneously recorded 2 episodes of intense precipitation were El Calafate (one episode from the 13th to 15th, and the other on the 18th), Puerto Deseado (the first one on the 14th and the second one on the 18th) and Perito Moreno (the first one on the 14th and the second one on the 18th). The remaining stations, located within the area of study, recorded intense precipitation during one of the 2 episodes: San Julian recorded the first episode (on the 13th and 14th) and Comodoro Rivadavia documented the second episode, whereas Paso de Indios had only moderate precipitation on the 18th. Therefore, for central Eastern Patagonia, the first episode of intense precipitation can be roughly defined as between the 13th and 15th, and a second episode between the 18th and 19th.

In the western counterpart to central Eastern Patagonia in Chile, there are few meteorological stations. The Lord Cochrane station, the closest one to Gobernador Gregores, recorded intense precipitation $(23 \mathrm{~mm}$ ) only on the 14th and very weak precipitation during the remaining period (Table 1). A little further north, Chile Chico recorded intense precipitation on the 14th $(20 \mathrm{~mm})$ and the 18th $(17.8 \mathrm{~mm})$, less than was recorded on both days at Gobernador Gregores. Also, in Balmaceda, precipitation was weak to moderate (Table 1). During the heavy rainfall event that was recorded in central Eastern Patagonia, it also rained in some areas of central Western Patagonia; however, the recorded precipitation was not considered an extraordinary event in this region. To meteorologically illustrate the event, the corresponding weather synopsis is depicted below.

The main associated meteorological tropospheric conditions during each episode of rainfall are shown in Fig. 7 (the panels from A1, B1 and C1 to A5, B5 and C5) using ERA-Interim data. Gauge station data were also described using hourly observations. The first rains started to fall on the 12th March at the Gobernador Gregores station. Early in the morning, ENE winds were recorded and a slight rain started to fall, accumulating $0.5 \mathrm{~mm}$. ENE winds blew all day long until the morning of the 13th. Enough rain fell so that the daily accumulated precipitation totaled $17 \mathrm{~mm}$. The rains continued during the day and the following morning, so the daily accumulated precipitation totaled $24 \mathrm{~mm}$ on the 14th, which was the maximum amount for the station during the entire weather event (Table 1). The surface weather maps from the 13th to the 14th (Fig. 7A1,A2) displayed an

Table 1. Weather station data from 12 to 21 March 2002: $10 \mathrm{~m}$ wind direction at Gobernador Gregores station, together with daily accumulated precipitation (in $\mathrm{mm}$ ) measured at Patagonia's meteorological stations. The numbers correspond to station site in Fig. 1. T: traces of precipitation; -: no precipitation

\begin{tabular}{|c|c|c|c|c|c|c|c|c|c|c|c|}
\hline Meteorological Station & Coordinates & $\begin{array}{c}12 \\
\text { ENE }\end{array}$ & $\begin{array}{c}13 \\
\text { ENE }\end{array}$ & $\begin{array}{c}14 \\
\text { ENE }\end{array}$ & $\begin{array}{c}15 \\
\text { SW }\end{array}$ & $\begin{array}{c}16 \\
\text { SSW }\end{array}$ & $\begin{array}{c}17 \\
\text { ENE }\end{array}$ & $\begin{array}{c}18 \\
\text { ENE }\end{array}$ & $\begin{array}{c}19 \\
\text { NNE }\end{array}$ & $\begin{array}{c}20 \\
\text { NNW }\end{array}$ & $\begin{array}{l}21 \\
W\end{array}$ \\
\hline Gobernador Gregores (3) & $48.77^{\circ} \mathrm{S}, 70.25^{\circ} \mathrm{W}$ & 0.5 & 17 & 24 & 7 & $\mathrm{~T}$ & - & 22 & 1 & - & - \\
\hline Lord Cochrane (22) & $47.23^{\circ} \mathrm{S}, 72.55^{\circ} \mathrm{W}$ & 4.2 & 0.4 & 23 & - & - & - & 3.8 & - & 2.6 & 8.1 \\
\hline Chile Chico (7) & $46.55^{\circ} \mathrm{S}, 71.7^{\circ} \mathrm{W}$ & 3.4 & 2.2 & 20.0 & - & - & - & 17.8 & 2.6 & - & 8.8 \\
\hline Balmaceda (6) & $45.91^{\circ} \mathrm{S}, 71.68^{\circ} \mathrm{W}$ & 0.8 & 4.0 & 6.0 & 0.0 & 0.4 & - & 9.6 & 0.2 & 0.4 & 4.4 \\
\hline Rio Gallegos (4) & $51.61^{\circ} \mathrm{S}, 69.28^{\circ} \mathrm{W}$ & - & 9 & 10 & 25 & 0.7 & 3 & - & 0.2 & 2 & $\mathrm{~T}$ \\
\hline San Carlos de Bariloche (5) & $41.15^{\circ} \mathrm{S}, 71.16^{\circ} \mathrm{W}$ & 2 & 6 & 32 & 11 & 14 & - & - & - & - & - \\
\hline Perito Moreno (8) & $46.52^{\circ} \mathrm{S}, 71.02^{\circ} \mathrm{W}$ & 4 & 1 & 14 & - & - & - & 11 & - & $\mathrm{T}$ & 1 \\
\hline El Calafate (9) & $50.27^{\circ} \mathrm{S}, 72.05^{\circ} \mathrm{W}$ & $\mathrm{T}$ & 27 & 33 & 22 & 3 & 0.6 & 21 & $\mathrm{~T}$ & $\mathrm{~T}$ & - \\
\hline El Bolsón (10) & $41.97^{\circ} \mathrm{S}, 71.52^{\circ} \mathrm{W}$ & 1 & 6 & $\mathrm{~T}$ & 32 & 6 & - & - & - & 12 & 2 \\
\hline Puerto Deseado (11) & $47.75^{\circ} \mathrm{S}, 65.89^{\circ} \mathrm{W}$ & - & 2 & 11 & - & 0.9 & 0.5 & 2 & 12 & 1 & - \\
\hline San Julian (12) & $49.31^{\circ} \mathrm{S}, 67.80^{\circ} \mathrm{W}$ & - & 21 & 28 & 3 & 2 & - & 0.3 & - & 0.5 & - \\
\hline Maquinchao (13) & $41.25^{\circ} \mathrm{S}, 69.42^{\circ} \mathrm{W}$ & - & 0.6 & 0.6 & - & - & - & - & - & - & - \\
\hline Chapelco (14) & $40.14^{\circ} \mathrm{S}, 71.25^{\circ} \mathrm{W}$ & - & 18 & 13 & 5 & 8 & - & - & - & - & - \\
\hline Viedma (15) & $40.85^{\circ} \mathrm{S}, 63.02^{\circ} \mathrm{W}$ & - & - & 15 & - & 0.6 & - & 5 & 0.7 & - & - \\
\hline San Antonio Oeste (16) & $40.78^{\circ} \mathrm{S}, 65.10^{\circ} \mathrm{W}$ & - & - & 17 & - & - & - & 5 & $\mathrm{~T}$ & - & - \\
\hline Esquel (17) & $42.93^{\circ} \mathrm{S}, 71.15^{\circ} \mathrm{W}$ & - & - & - & - & - & - & $\mathrm{T}$ & - & $\mathrm{T}$ & 0.9 \\
\hline Paso de Indios (18) & $43.81^{\circ} \mathrm{S}, 68.88^{\circ} \mathrm{W}$ & - & - & - & - & - & - & 9 & - & - & - \\
\hline Puerto Madryn (19) & $42.76^{\circ} \mathrm{S}, 65.10^{\circ} \mathrm{W}$ & - & - & - & - & - & - & 6 & - & - & - \\
\hline Trelew (20) & $43.21^{\circ} \mathrm{S}, 65.27^{\circ} \mathrm{W}$ & - & - & - & - & - & - & 3 & - & 0.3 & - \\
\hline Comodoro Rivadavia (21) & $45.78^{\circ} \mathrm{S}, 67.50^{\circ} \mathrm{W}$ & - & - & - & - & - & - & 28 & 3 & 0.2 & - \\
\hline
\end{tabular}


First episode
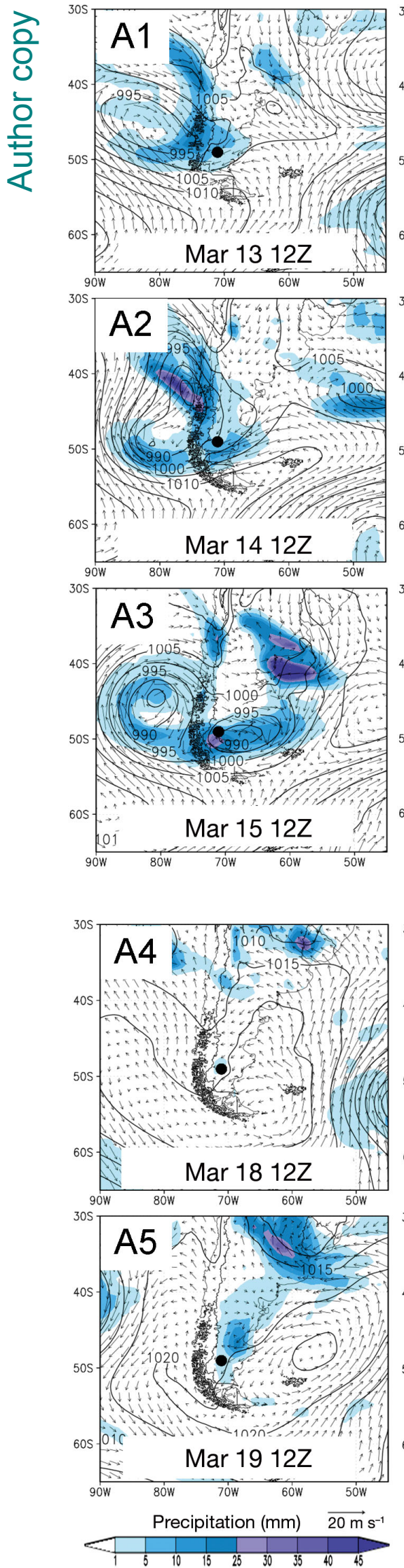
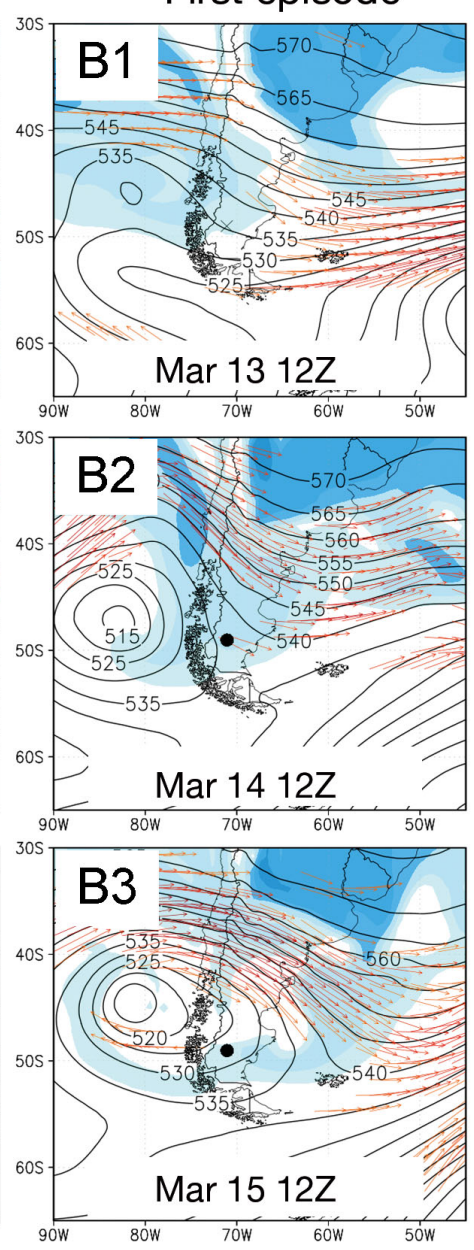

\section{Second episode}
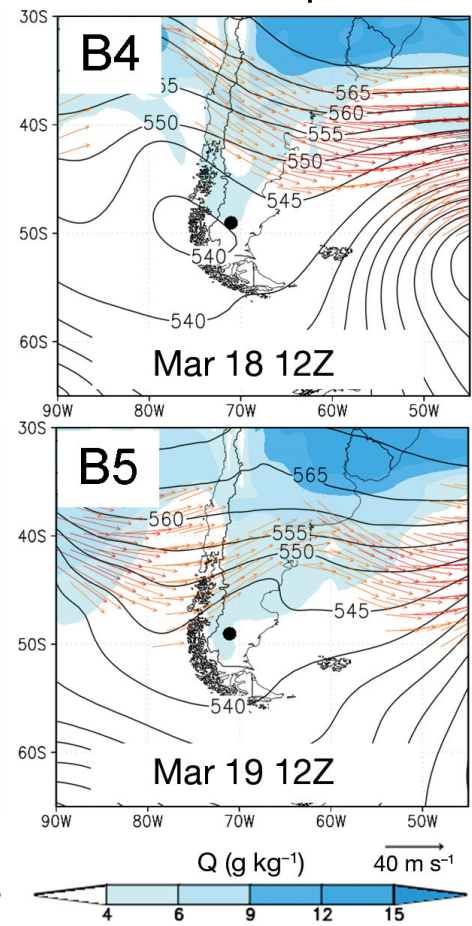
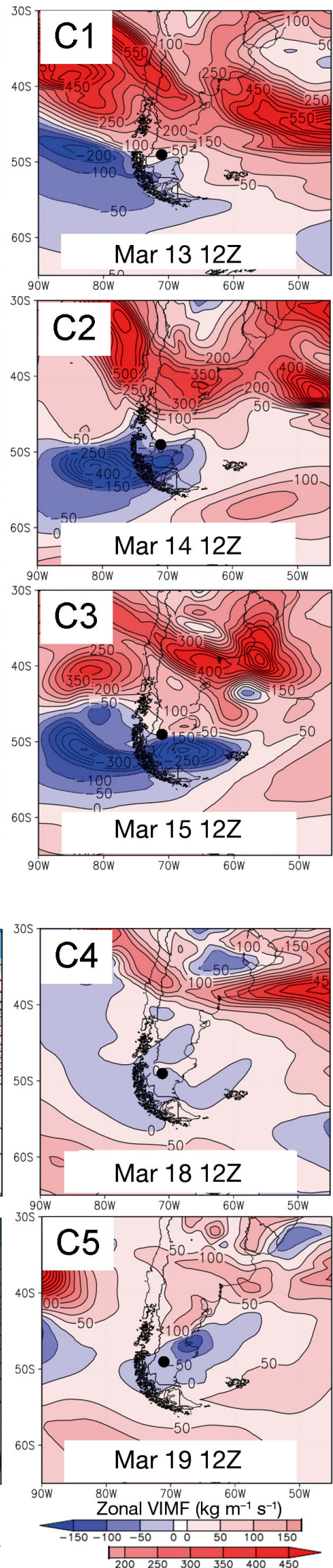

Fig. 7. Synoptic meteorological situation for southern South America using reanalysis dataset. Weather maps from 13-15 March (first episode of heavy rainfalls; $12 \mathrm{Z}$ indicates the synoptic hour, corresponding to noon at Greenwich) and 18 and 19 March (second episode of heavy rainfall) 2002: Panels (A1-A5) sea level pressure contours $(\mathrm{hPa})$, surface winds and total precipitation; (B1-B5) geopotential height contours at $500 \mathrm{hPa}$, wind vectors at $300 \mathrm{hPa}$ (only values $>27 \mathrm{~m} \mathrm{~s}^{-1}$ are displayed [red arrows], corresponding to the jet stream) and specific humidity Q at $850 \mathrm{hPa}_{i}$ (C1-C5) zonal moisture transport given by the zonal VIMF. Black dot indicates the Lago Cardiel location 
incoming cyclone at $45^{\circ} \mathrm{S}$ to the west of Western Patagonia together with a concomitant anticyclone to the southwest and a typical cold front. Throughout the day before and up to the 13th, the gradual incursion of the low into central Eastern Patagonia produced a turning of surface winds from the east and ERA-Interim derived TP increased in the area. In the mid-troposphere, the leading edge of a diffluent trough provided gradual dynamic ascent of an air mass in northern Andean Patagonia (figures not shown). The trough axis, located westward offshore over the Pacific, was linked to a closed pressure low that gradually deepened through time and remained quasistationary between the 13th and 15th (Fig. 7B1-B3). The upper tropospheric jet stream located over northern Patagonia accompanied the system, gradually providing upper level divergence that further induced air to rise. The moistening of the lower troposphere in central and southern Eastern Patagonia became apparent especially after the 13th onwards. On the 12th, the prevalent moisture transport from the west started to grow into westward moisture flux during the morning of the 13th, south of the Lago Cardiel area (figures not shown). On the 14th, the reanalysis TP extended over central and southern Eastern Patagonia (Fig. 7A2). Meteorological station data indicated that intense precipitation was gauged at San Carlos de Bariloche in Argentine Andean Patagonia, far to the northwest of Lago Cardiel, probably due to frontal and orographic effects (Table 1). Heavy rains also fell over an extended area south of Lago Cardiel as indicated by the reanalysis TP (Fig. 7A2) and by the accumulated rainfall gauged at the stations of Rio Gallegos, San Julian and El Calafate (Table 1). The extended area of heavy rainfall was located where westward moisture transport prevailed (Fig. 7C2).

Between the 14th and 15th, a cyclogenesis generated a westward moving zonally elongated low-level cyclone over the east of central Eastern Patagonia (Fig. 7A2,A3). Downstream of the surface cyclone, an incursion of high pressure high ridge enhanced easterly winds on the 14th. The new surface cyclone progressed to the southeast, and was located off the coast on the 16th. The upper cyclone slowly split on the 15th and generated another upper cyclone on the 16th accompanying the surface cyclone (figures not shown). Meanwhile, the entire area to the southsoutheast of the Lago Cardiel was under the influence of net westward moisture transport on the 15th (Fig. 7C3). The station of Rio Gallegos, located in the core area of the westward moisture transport, recorded its maximum precipitation $(25 \mathrm{~mm})$ on the 15th, which was also shown by the reanalysis TP (Fig. 7A3). The station of Gobernador Gregores recorded winds from SW-SSW and an accumulated rainfall of $7 \mathrm{~mm}$.

Between the 16th and 17th, the former surface cyclone moved further east off the coast, leaving central Eastern Patagonia with light southern surface winds and a moderate predominance of westward moisture transport growing later into eastward moisture flow accompanied by surface easterly winds (not shown). These $2 \mathrm{~d}$ were characterised by the absence of significant precipitation in the area. From the night of the 17th, Gobernador Gregores recorded ENE winds that prevailed for 2 more days (Table 1).

On the 18th (Fig. 7A4), a surface high entered in area from the southwest, bringing generalised surface easterlies toward the interior of central Eastern Argentina until the 20th. In the mid-troposphere, a closed low pressure dominated the dynamics on the 18th (Fig. 7B4) and was replaced by an incoming ridge between the 19th and the 20th (figures not shown). Meanwhile, on the nights of the 18th and 19th, the tropospheric moisture transport intensified toward the west (Fig. 7C4,C5). Because of the combination of the upper cyclone together with low level moisture, Gobernador Gregores recorded $23 \mathrm{~mm}$ of precipitation on the 18th and Puerto Deseado received $12 \mathrm{~mm}$ on the 19th (Table 1). Moreover, the Atlantic coastal station of Comodoro Rivadavia, north of the study area, recorded its only event of intense precipitation $(28 \mathrm{~mm}$ ) on the 19th (Table 1 ). The station is located right where the major moisture transport from the Atlantic occurred that day (Fig. 7C9). Afterwards, on the 20th, although surface easterlies were present, no precipitation was recorded (Table 1), since an upper ridge of high pressure dominated the area (not shown). Finally, on the 21st, strong surface westerlies started to blow again over central Eastern Patagonia (not shown).

Quasi-stationary tropospheric circulation structure associated with the full period of heavy rainfall (averaged from the 12th to 20th March) in central Eastern Patagonia could be described as a meridional pressure dipole that encompassed the whole troposphere with an anomalous high to the south and an anomalous low to the north, to the west of $70^{\circ} \mathrm{W}$ in the southeastern South Pacific based on the daily geopotential anomalies at $850 \mathrm{hPa}$ and $300 \mathrm{hPa}$ averaged over the period (Fig. 8a,b). Although only the 13th, 14th and 15th and 17th of March can be categorized as blocking action days according to the TM's blocking index at $80^{\circ}$ and $60^{\circ} \mathrm{W}$, respectively, such blocking-like tropospheric flow, on average, weak- 
ened the westerlies throughout central Patagonia and favoured an effective mean net westward moisture transport from the Atlantic (Fig. 8c).

Moreover, such quasi-stationary synoptic atmospheric flow and the concomitant heavy precipitation pattern affected the monthly precipitation and lower 2002 (Fig. 9a,b). The monthly precipitation anomaly field depicted a west-east precipitation dipole at about $50^{\circ} \mathrm{S}$ between dry central Western Patagonia (west) and wet central Eastern Patagonia (east), as well as a north-south precipitation gradient between a wetter central Eastern Patagonia (north) and a drier Southern Patagonia (south). Hence, as long as mean dipolar precipitation anomalies prevail in central and southern Patagonia, they could be interpreted as a consequence of an increment in the frequency of slow-moving weather systems crossing over Patagonia around $50^{\circ} \mathrm{S}$ and inducing easterly moisture flux. The 1940s precipitation anomalies could be an example of this assertion (Section 3.1). In other words, if more frequent blocking-like flow events are observed over the southeastern South Pacific and southwestern South Atlantic Oceans over a long period of time, then dipolar precipitation anomalies level tropospheric circulation anomalies for March

can be expected in central-south Patagonia. Such a conceptual framework was applied in the following section in order to provide a deeper understanding of palaeoclimatic reconstructions of the area in accordance with the climate scenarios produced by GCMs during the Holocene.

\subsection{Palaeoclimatic variability in Lago Cardiel during the Holocene}

An increasing number of palaeoclimatic studies have been produced using lake sediments during recent decades in Eastern Patagonia (Ariztegui et al. 2001, Ariztegui et al. 2008). In particular, the hydrologically closed Lago Cardiel lake basin (Fig. 1) has been studied because it is decoupled from present and past glacial or melt water input (Stine \& Stine 1990, Gilli et al. 2001). Therefore, changes in the lake level are mainly due to changes in the hydrological balance produced by precipitation over the lake catchment area. Thus, Lago Cardiel is an ideal site with a proxy record that can be used to infer climate links between precipitation and zonal moisture transport in central Eastern Patagonia at palaeoclimatic scales. a) $850 \mathrm{hPa}$ GPH anomaly

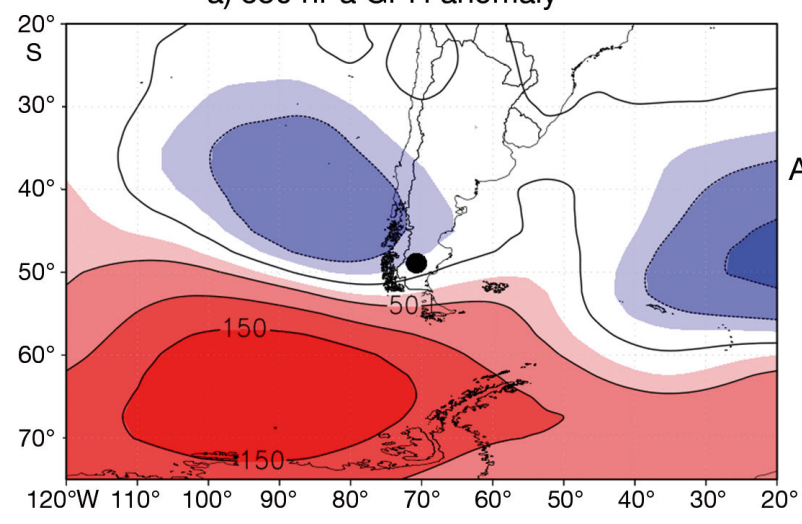

b) $300 \mathrm{hPa}$ GPH anomaly

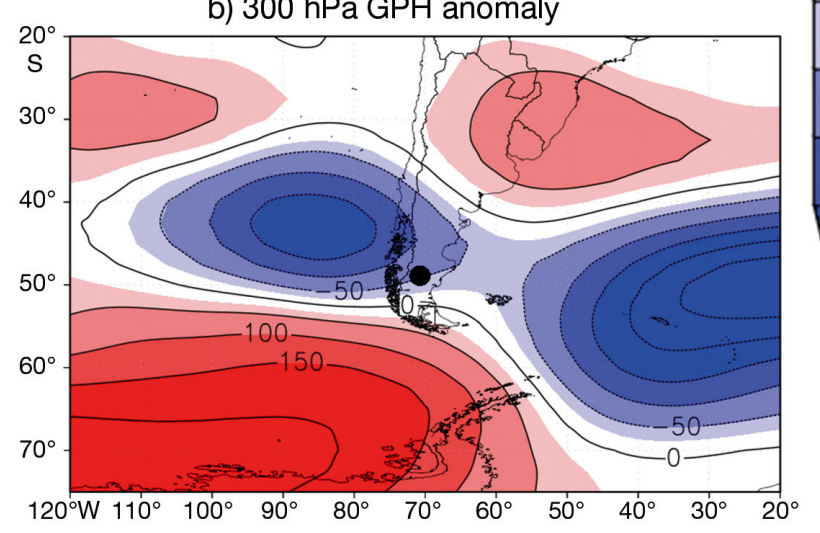

c) Net zonal moisture transport

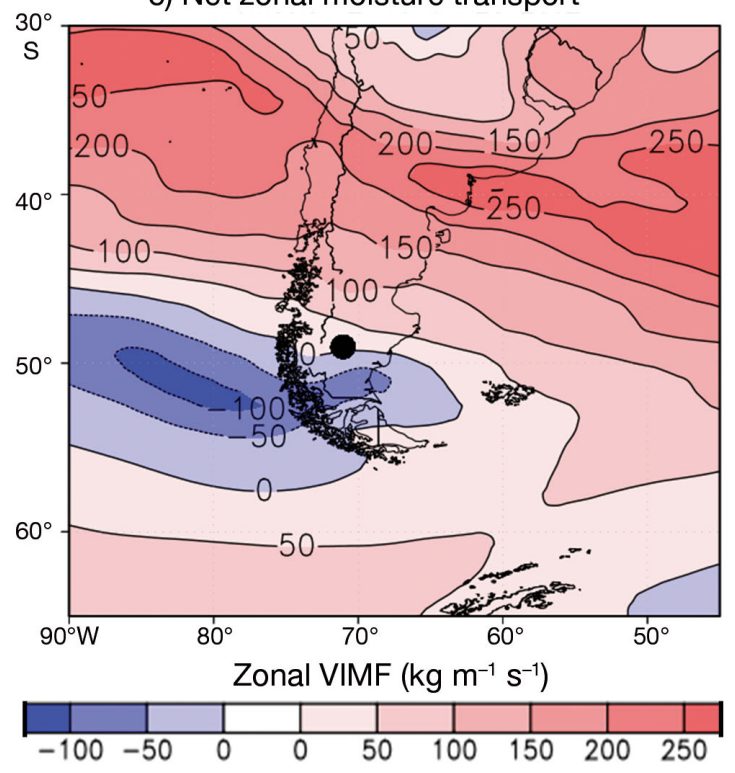

$-150$

Fig. 8. Averages over the entire period of the heavy rainfall event of March 2002 at Gobernador Gregores (between 12 and $20 \mathrm{March}$ ) for (a) $850 \mathrm{hPa}$ geopotential height (GPH) (contours and colour shades in $\mathrm{m}$ ), expressed as anomaly with respect to monthly climatology for 1981-2010, (b) 300 hPA GPH and (c) net zonal moisture transport, given by the values of zonal VIMF. Colour shades-blue: westward (negative) and red: eastward (positive) VIMF values 
a) TP anomaly, March 2002

응
ㅇ
을
달

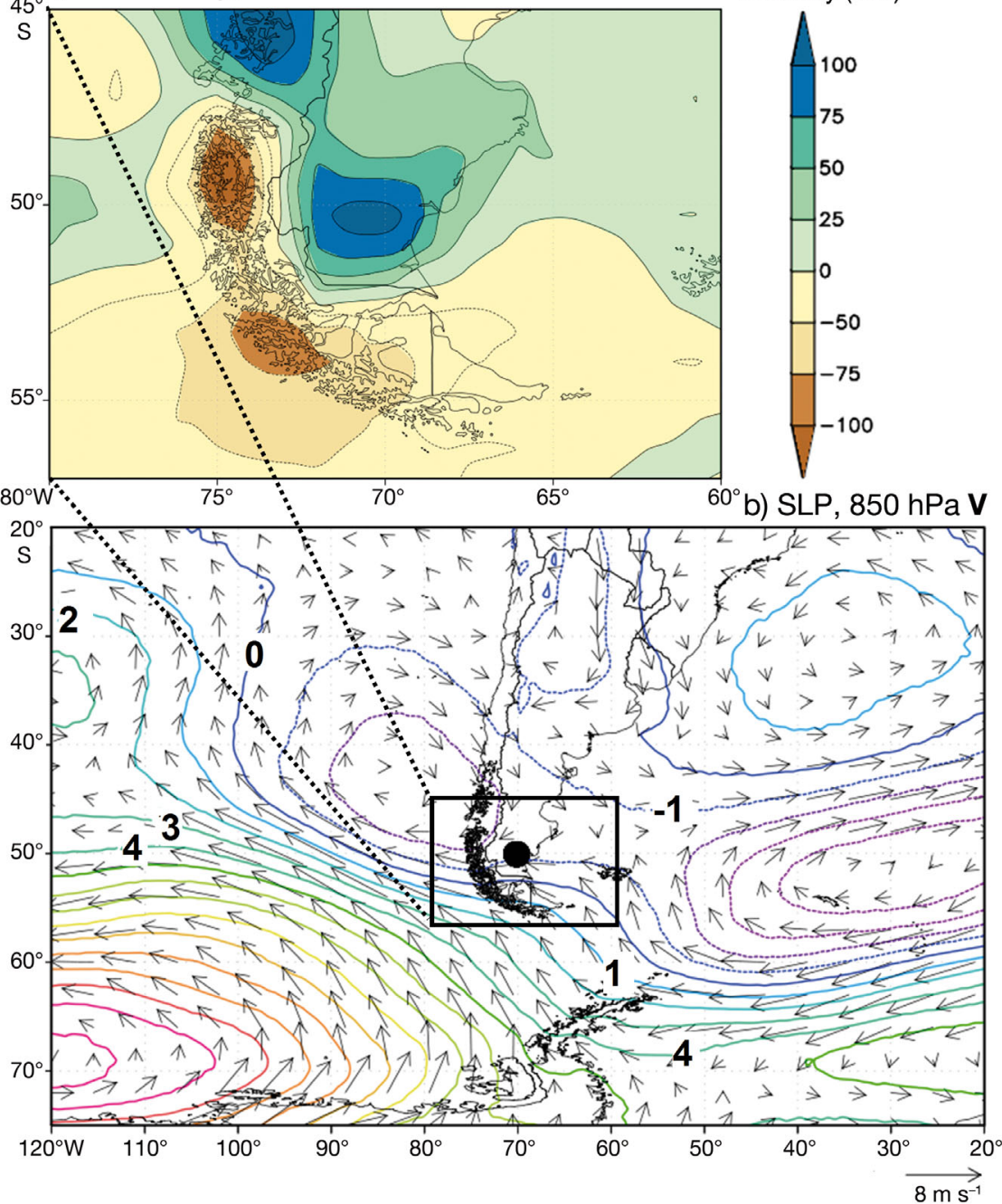

Fig. 9. (a) ERA-Interim monthly total precipitation (TP) anomaly for March 2002, with respect to 1981-2010, (b) ERA-Interim sea level pressure (SLP, contours every $1 \mathrm{hPa}$; colours represent intensity of anomaly: red to blue-high to low), and ERA-Interim $850 \mathrm{hPa}$ vector wind (V, arrows)

early Holocene, extending approximately between 11000 and $8000 \mathrm{cal} \mathrm{yr}$ $\mathrm{BP}$, reaching $+55 \mathrm{~m}$ at $10800 \mathrm{cal}$ yr BP. The other peak occurred during the mid Holocene at $+23.5 \mathrm{~m}$. After that, the estimated lake levels ranged from approximately $+10 \mathrm{~m}$ to almost zero, which corresponds to the modern level depth of $73 \mathrm{~m}$.

Moreover, changes in the $\delta^{18} \mathrm{O}$ isotopic composition suggest an inverse relationship with lake water level. A decreased composition was observed at times with higher water levels as: $-4.2 \%$ when lake levels were similar to the modern value at $3230 \mathrm{cal} \mathrm{yr}$ $\mathrm{BP} ;-5.5 \%$ when the lake level was $+21.5 \mathrm{~m}$ at $\sim 6000 \mathrm{cal}$ yr BP and $-6.5 \%$ when the lake level was $+55 \mathrm{~m}$ at $10800 \mathrm{cal}$ yr BP. Conversely, the highest value of $\delta^{18} \mathrm{O}(-1.5 \%$ ) characterises times when lake levels were lower during the Late Pleistocene. Since the Lago Cardiel is a closed watershed and uncoupled from water inputs from glacier and snow melt, both presently and in the past, isotopic changes observed in carbonates were not directly related to changes in the $\delta^{18} \mathrm{O}$ of ice and/or snow accumulated in the Andean region. The isotopic fractionation was affected by several factors, among them, the intensity of the precipitation known as the 'amount effect'. This implies that the greater the amount of rainfall, the lower its $\delta^{18} \mathrm{O}$ values (Dansgaard 1964, Rozan-

Combined seismic and sedimentological investigations of the lake basin have provided a record of the lake-level changes for the Late Pleistocene and Holocene (Markgraf et al. 2003, Gilli et al. 2001, 2005, Haberzettl et al. 2005, Anselmetti et al. 2009). Additionally, the lake-level record coupled with other palaeoclimatic records located in Patagonia revealed substantial climate changes in the region (Ariztegui et al. 2010, Fletcher \& Moreno 2012, Kilian \& Lamy 2012, Zolitschka et al. 2013). The water level of Lago Cardiel relative to the modern depth $(73 \mathrm{~m})$ is shown in Fig. 10a, together with oxygen isotopes $\left(\delta^{18} \mathrm{O}\right)$ of carbonates precipitated from the water column or 'authigenic' taken from Gilli (2003). There were 2 periods when lake levels were higher than the modern value. The most relevant peak corresponds to the ski et al. 1992, Risi et al. 2008). Therefore, increased lake water level together with decreased $\delta^{18} \mathrm{O}$ values recorded in central Eastern Patagonia during $\sim 6000 \mathrm{cal} \mathrm{yr} \mathrm{BP}$ and around 8000-11000 cal yr BP may suggest an increase in episodes of intense precipitation in the area. In turn, changes in $\delta^{18} \mathrm{O}$ depend on changes in the moisture source area (McKenzie \& Hollander 1993, Mayr et al. 2007). Despite the lack of data on the isotopic signature of rainfall in the region, it appears that the isotopic composition of Atlantic rainfall was more negative than that coming from the west, as suggested by the data from Rozanski et al. $(1992,1993)$ showing $-8.0 \%$ at Port Stanley $\left(51.78^{\circ} \mathrm{S}, 57.85^{\circ} \mathrm{W}\right),-10.5 \%$ at Ushuaia $\left(54.80^{\circ} \mathrm{S}, 68.30^{\circ} \mathrm{W}\right)$ and $-5.7 \%$ at Puerto Montt $\left(41.47^{\circ} \mathrm{S}, 72.93^{\circ} \mathrm{W}\right)$. The possible dependence of the 


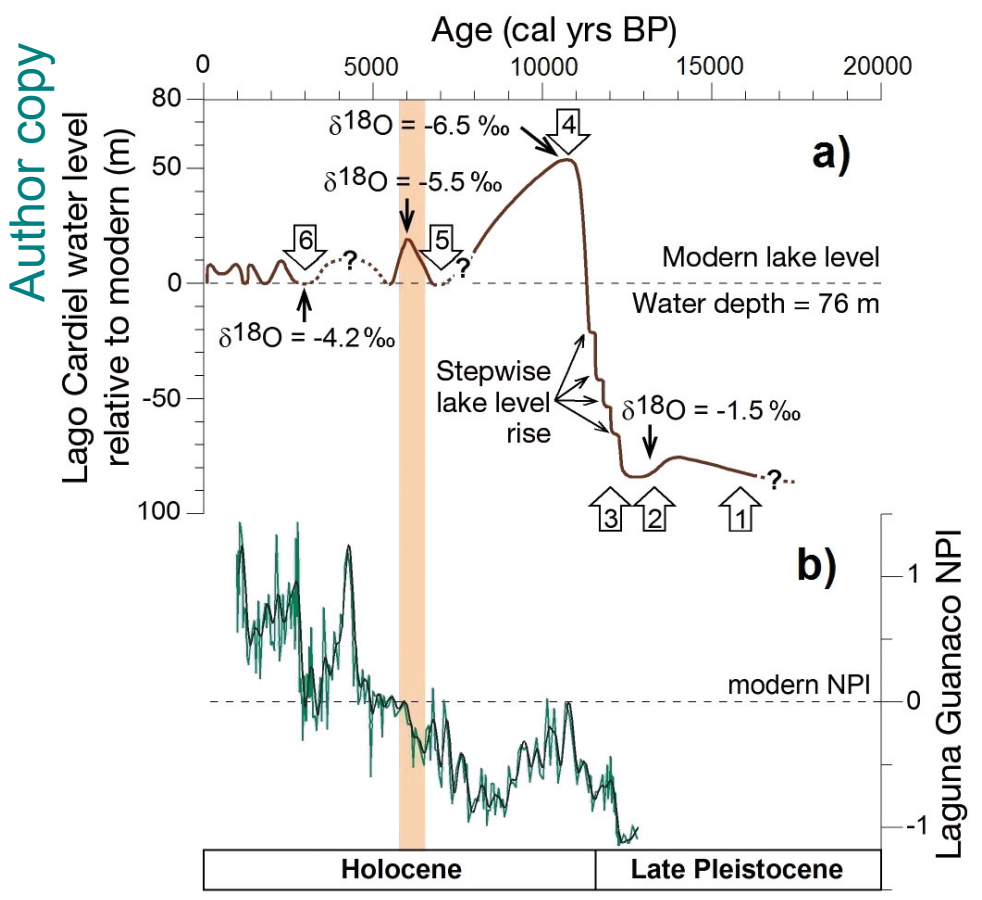

Fig. 10. (a) Reconstructed lake-level curve for Lago Cardiel combining geophysical and sedimentological data (Stine \& Stine 1990, Gilli et al. 2001). Numbered arrows indicate radiocarbon or tephra ages as follows: (1) Reclús tephra 15330 calibrated (cal) yr BP, (2) $13160 \mathrm{cal} \mathrm{yr} \mathrm{BP,} \mathrm{(3)} 12320 \mathrm{cal} y r$ BP, (4) $10800 \mathrm{cal} \mathrm{yr} \mathrm{BP,} \mathrm{(5)} \mathrm{Hudson} \mathrm{tephra} 7570 \mathrm{cal}$ yr BP and (6) 3230 cal yr BP from Ariztegui et al. (2008, and references therein) and values of $\delta^{18} \mathrm{O}$ (from Gilli 2003). (b) Lago Guanaco Nothofagus/Poaceae index (NPI) raw (green line) and smoothing data (from Moreno et al. 2010). Beige band illustrates opposing behaviour of Lakes Cardiel and Guanaco (see Section 3.4 for further details)

isotopic fraction on latitude would weaken the prior supposition.

Furthermore, if the mid-Holocene lake-level increase had corresponded to an increase in precipitation produced by moisture transport from the Pacific, as is frequently interpreted in the literature because of the westerlies paradigm, rainfall in the Western Patagonian latitudinal counterpart would have also increased. The latter fact is actually what happens in the present climate when moisture transport is westward (see Fig. 6c). However, the reconstructed paleoenvironment seems to show the opposite: Moreno et al. (2010) reported dry conditions in the Guanaco Chilean Lake $\left(51^{\circ} \mathrm{S}\right)$ at $6000 \mathrm{cal}$ yr BP, located near the modern forest-steppe transition. Fig. 10b shows the normalised Nothofagus (southern beech)/Poaceae (grass) index (NPI) based on the palynology (thick black lines represent the smoothed and the green the raw index values) in the Lago Guanaco area. Positive anomalies of the NPI represent the preeminence of southern beech scrublands and/or woodlands under wetter conditions and negative anomalies are indicative of the dominance of the Patagonian steppe under drier conditions (Moreno et al. 2010). During the period with high water levels at Lago Cardiel, between $\sim 11000 \mathrm{cal}$ yr BP and $\sim 5500 \mathrm{cal}$ yr BP, the NPI index showed negative values. At $\sim 5500, \sim 7000$ and $\sim 11500 \mathrm{cal}$ yr BP, both lake records were nearly zero (modern values). After the mid-Holocene, while the NPI increased (representing wetter conditions, i.e. enhanced precipitation on the Chilean side), the Lago Cardiel water level decreased with values oscillating between $+10 \mathrm{~m}$ and zero (i.e. values near $73 \mathrm{~m})$. For the Late Pleistocene, the inverse relationship between both lakes seemed to be lost.

In brief, the palaeoclimatic reconstructions depicted an increase in the Lago Cardiel lake levels and dry conditions in the Lago Guanaco $\left(51.25^{\circ} \mathrm{S}, 72.25^{\circ} \mathrm{W}\right)$ environment during the mid-Holocene, suggesting increased precipitation in central Eastern Patagonia and decreased precipitation in the Western Patagonian latitudinal counterpart. Likewise, a pair of proxy records located $10^{\circ}$ north of Lago Cardiel to the west of the Andes could provide additional evidence for the assumption. One proxy was a marine sediment core (GeoB 3313-1), obtained and analyzed by Lamy et al. (2001), from the upper continental slope off southern Chile at $41^{\circ} \mathrm{S}, 74.45^{\circ} \mathrm{W}$ (not shown), which contained higher inputs of iron-poor material during more humid periods. The authors suggested that generally less humid conditions occurred from 7700 to $4000 \mathrm{cal}$ yr BP (mid-Holocene), peaking between 6000 and 5300 cal yr BP. During the last 4000 cal yr BP (late Holocene), climate conditions were more humid on average. Hence, the results were in general agreement with previous ones from higher latitudes. However, for the mid-Holocene, Lamy et al. (2001)'s inferences are in disagreement with those of Moreno et al. $(2004,2010)$ obtained from the other proxy data consisting of the pollen record for Lago Condorito $\left(41.76^{\circ} \mathrm{S}, 73.12^{\circ} \mathrm{W}\right.$. Figures not shown) located at the same latitude. The pollen data was interpreted as warm, relatively dry conditions during the early Holocene between 10000 and $8000 \mathrm{cal}$ yr BP, followed by a cooling event and increased precipitation during the mid-Holocene, reaching its maximum at $5000 \mathrm{cal} \mathrm{yr}$ BP. As a consequence, there are inconsistencies among the mid-Holocene proxies near $41^{\circ} \mathrm{S}$. Such a discrepancy between the 2 terrestrial Chilean sites for the second part of the Holocene requires additional future investigations.

Therefore, according to the palaeoclimatic reconstructions described above, during the early and mid-Holocene, increased Lago Cardiel lake levels 
and dry conditions in the Lago Guanaco environment were observed. The hydrological balance suggests increased precipitation in central Eastern Patagonia and decreased precipitation in the Western Patagonian latitudinal counterpart. Along with the current findings supported by the analysis described in the previous sections, it is possible to assess the physical nature of the inverse wet and dry signals between Eastern and Western Patagonia at these latitudes. Accordingly, a weakening of the westerlies dries Western Patagonia and allows additional moisture transport from the Atlantic, moistening central Eastern Patagonia under synoptic blocking-like flow.

The mean climatic conditions that correspond to the previous inference of precipitation patterns were described by recent GCM outcomes that offer insight to climate scenarios for the mid-Holocene. Wagner et al. (2007) performed transient climate simulations for 7000-4500 cal yr BP period using a coupled atmosphere-ocean GCM, driven by forcing combinations of orbital, solar and greenhouse gases, compared to pre-industrial levels. They obtained higher precipitation during the mid-Holocene from March to August, higher annual means and reduced precipitation from September to February. The simulations also showed stronger westerlies over southern Patagonia during austral summer related to reduced pressure south of $50^{\circ} \mathrm{S}$. During winter, the circulation pattern outcome was different, with increased pressure southwest of southern South America. The maximum differences arose around $60^{\circ} \mathrm{S}$, resulting in reduced pressure gradients and weaker westerlies (see the JJA SLP in Wagner et al. 2007, their Fig. 10). In others words, the SLP anomaly pattern during winter corresponded closely to the $850 \mathrm{mb}$ geopotential anomaly field obtained previously for March 2002, which was associated with the synoptic scale blocking action (Fig. 8a,b \& Fig. 9b).

Moreover, Rojas \& Moreno (2011) analyzed the complete Palaeoclimate Modelling Inter-comparison Project (PMIP2) database of simulations from $6000 \mathrm{cal}$ yr BP compared to pre-industrial values, calculating the ensemble mean of 13 coupled OceanAtmosphere GCMs monthly mean data. The largest insolation differences occurred in fall (MAM, negative anomalies) and spring (SON, positive anomalies). Over southern South America, the atmospheric circulation pattern (see in Fig. 9 in Rojas \& Moreno 2011) during DJF and MAM was dominated by a strong northwesterly flow (part of a cyclonic wind anomaly) around a negative sea level pressure anomaly that was centered at about $100^{\circ} \mathrm{W}$. At the southern flank of this anomaly, zonal easterly wind anomalies, i.e. weaker westerlies, affecting southern Patagonia were associated with an anticyclonic SLP anomaly centered between $60^{\circ}$ and $70^{\circ} \mathrm{S}$ over the South Pacific westward to $110^{\circ} \mathrm{W}$. The configuration of anomalies was similar to the one shown in Fig. 10b for the present climate. Hence, such a meridional dipole of SLP can denote a major blocking-like flow situation affecting the westerlies during $6 \mathrm{kyr}$ BP compared to the pre-industrial period. This pattern was most noticeable in fall when the zonally extended area of easterly wind anomalies was located further north than in summer, with the northern flank reaching $50^{\circ} \mathrm{S}$. The latitudinal band of easterly wind anomalies expanded northward up to $\sim 45^{\circ} \mathrm{S}$ during winter, which covered the region of Lago Cardiel catchment area. The situation was reversed during spring with positive sea level pressure anomalies centered around $100^{\circ} \mathrm{W}$ and $35^{\circ} \mathrm{S}$, strengthening the South Pacific semi-permanent anticyclone. Therefore, only during MAM and JJA did the anomalous tropospheric circulation conditions reported by Rojas \& Moreno (2011) reveal weakened westerlies that could ultimately be associated with the rise of the Lago Cardiel water level through increased westward moisture transport from the Atlantic. Likewise, these inferences could be deduced from the results of Wagner et al. (2007) described above.

More recently, Pollock \& Bush (2013), through the use of a meso-scale model forced by global atmosphere-ocean model data, produced scenarios for $6000 \mathrm{cal} \mathrm{yr} \mathrm{BP}$ and $9000 \mathrm{cal}$ yr BP using the preindustrial control as reference for the anomalies. In particular, the high resolution scenario of $9000 \mathrm{cal}$ yr BP minus the control showed that southeasterly wind vector anomalies dominated Patagonia south of $50^{\circ} \mathrm{S}$ (in Pollock \& Bush 2013, Fig. 7c). Under this atmospheric circulation anomaly, the model estimated a large increase in precipitation over the Lago Cardiel region against a sharp drop on the Chilean side in the region south of $49^{\circ} \mathrm{S}$ where Laguna Guanaco is located. Additionally, the authors showed a reduction in precipitation over the Argentinean region south of $52^{\circ} \mathrm{S}$, which is in agreement with proxy data from Laguna Potrok Aike $\left(51.97^{\circ} \mathrm{S}, 70.38^{\circ} \mathrm{W}\right)$ indicating low levels, between -10 and $-35 \mathrm{~m}$ with respect to modern levels (Anselmetti et al. 2009, Zolitschka et al. 2013). Therefore, for the $9000 \mathrm{cal} \mathrm{yr} \mathrm{BP}$, there were 2 dipoles of precipitation anomalies, one between the east (wet) and west (dry) sides of the Andes and the other between the north (wet) central Eastern Patagonia and the south (dry) Southern Patagonia. These findings are in overall agreement with the dipolar precipitation conditions estimated from 
proxy records for Lago Cardiel versus Lago Condorito, and for Lago Cardiel versus Laguna Potrok Aike, respectively.

The above GCM outcomes for the early and midHolocene showed a zonal dipole of precipitation anomalies between central Western and Eastern Patagonia, and between the latter and Southern Patagonia, as a result of decreased mean westerlies due to easterly wind anomalies and anomalous moist conditions over the Lago Cardiel area. Likewise, both the modelled precipitation dipoles and tropospheric circulation anomalies were comparable to the ones obtained here for the present climate (1979-2013). Therefore, it was expected that the occurrence of quasi-stationary synoptic flows was more favoured during the early and mid-Holocene. Under such a climate scenario, the established blocking-like atmospheric flow would induce additional westward moisture transport from the Atlantic, and consequently would induce positive precipitation anomalies over central Eastern Patagonia, especially during the austral fall and winter.

The only model that actually provided daily data for the mid-Holocene was the EC-Earth version 2.2 from the Royal Netherlands Meteorological Institute (KNMI), which can be used to identify synoptic weather systems. However, a validation of the model performed by Hazeleger et al. (2011) for actual scenarios showed a strong warm bias in the Southern Hemisphere extratropics close to the surface, compared to ERA-Interim reanalysis. In turn, the authors have shown that the Southern Annular Mode, a zonally symmetric pattern dominating $\mathrm{SH}$ atmospheric variability and dynamically linked to the westerlies (Thompson \& Wallace 2000), was more symmetric in the model. The bias of zonal symmetry was stronger in the southeastern South Pacific and southern South America, implying stronger westerlies than in ERA-Interim reanalysis. The latter indicates that EC-Earth is incapable of reproducing the natural variability of the mid-latitude westerlies in the vicinity of Patagonia. Furthermore, the seasonal tropospheric fields produced by the model in the Mid-Holocene experiment, when compared to the pre-industrial control experiment, reproduced anomalies that differed considerably from the ones previously described (figures not shown). The use of the past climate daily information provided by the model will definitely require an evaluation of the performance of the model to realistically understand the daily synoptic circulation patterns in the mid-tohigh SH latitudes and is beyond the scope of the current study.

\section{CONCLUSIONS}

The present study examined the hypothesis known as the 'westerlies rule'. It is an interpretative climatic tool that serves to help understand the time variations in climatic variables over Patagonia from the knowledge of changes in the position and intensity of the mid-latitude $\mathrm{SH}$ westerlies, and as such it has been widely used in the palaeoclimatic literature (Fletcher \& Moreno 2012). The emphasis of this study was placed on Lago Cardiel and its surroundings, in central Eastern Patagonia, since it is an ideal place which combines key factors to analyse present and past climates.

On one hand, the lake catchment area is a closed basin decoupled from present and past glacial or melt water input (Stine \& Stine 1990, Gilli et al. 2001). Thus, observed changes in the lake level are mostly due to changes in precipitation over the basin. The present climate variability of intense precipitation in central Eastern Patagonia has been exhaustively examined using observational data from several stations within the region and ERA-Interim reanalysis data.

From a decadal perspective, the 1940s was a relatively wet period during fall and spring in central Eastern Patagonia compared to the previous and following decades. The decadal precipitation anomalies were evaluated using the CRU and UDel gridded datasets and both showed similar spatial signals. The anomalies suggested a west-east dipolar precipitation pattern between the west (dry) and east (wet) sides of the Andes. We showed here that the precipitation increment recorded over central Eastern Patagonia could be linked to decadal anticyclonic anomalies of low-level troposphere circulation enhancing anomalous moist air mass inflow from the Atlantic. The daily scale significantly contributed to the decadal anomalies through an increase in the daily frequency of low-level easterlies and consequent westward moisture transport from the Atlantic. A complementary mechanism could be a less accentuated subsidence produced by the Andes due to weaker westerlies as suggested by Garreaud et al. (2013).

The analysis of the link between precipitation in the study area and zonal moisture transport on a daily scale provided insightful results. Although the total daily frequency of local westward moisture transport was low, since central Eastern Patagonia is located within the mid-latitude climatological eastward moisture flux band (Trenberth \& Guillemot 1998), precipitation in central Eastern Patagonia can occur under both westward and eastward moisture 
flux, though with a higher propensity under westerly moisture flux. Moreover, more (less) frequent local westward (eastward) moisture transports lead to increased daily precipitation intensity. Hence, the South Atlantic Ocean appears to be an additional source of moisture during intense precipitation events (daily accumulated $\mathrm{P} \geq 10 \mathrm{~mm}$ ), partly as result of slow-moving weather systems providing blocking-like flows over the region and adjacent oceans.

The composite precipitation anomaly field for those days with intense precipitation and strong local westward moisture transport at Gobernador Gregores station (the closest station to Lago Cardiel) depicted a west-east precipitation dipole at about $50^{\circ} \mathrm{S}$ between dry central Western Patagonia (west) and wet central Eastern Patagonia (east), as well as a north-south precipitation gradient between wet central Eastern Patagonia (north) and dry Southern Patagonia (south). The precipitation anomaly pattern resembled the monthly mean precipitation anomaly for March 2002, when a prolonged wet spell hit the region. Hence, as long as mean dipolar precipitation anomalies prevail in central and southern Patagonia, they can be interpreted as a consequence of enhanced additional easterly moisture flux from the Atlantic, due, in part, to more frequent slow-moving weather systems crossing over Patagonia along $50^{\circ} \mathrm{S}$. If for any reason blocking-like flow events are enhanced over the southeastern South Pacific and southwestern South Atlantic Oceans over a long period of time, then dipolar precipitation anomalies can be expected in central-south Patagonia. Future studies will further examine the relationships found among synoptic tropospheric circulation, precipitation and zonal moisture transport in Eastern Patagonia with respect to trends and time variability.

Lago Cardiel is particularly unique due to the fact that it has a water level proxy record available which has been used to infer palaeoclimatic scale variations in the lake level. Following previous studies, it was possible to assess that, during the mid-Holocene, the palaeoclimatic reconstructions depicted an increase in the Lago Cardiel water levels and dry conditions in Lago Guanaco (located west of the Andes roughly at the same latitude as Lago Cardiel), as well as low water levels for the Laguna Potrok Aike southwards (also for the early Holocene). This suggests increased precipitation in central Eastern Patagonia and decreased precipitation in central Western Patagonia and Southern Patagonia.

The mean tropospheric circulation conditions corresponding to the former inference of precipitation anomalies were described by the most relevant GCM outcomes providing climate scenarios for the early and mid-Holocene. In general, the GCM scenarios were in agreement with proxy record reconstructions. Both the modelled precipitation dipoles and tropospheric circulation anomalies were very similar to the ones obtained in our current study of the present climate. Therefore, it is expected that the occurrence of quasi-stationary synoptic flows was more favoured during the early and mid-Holocene. More blocking-like atmospheric flow near the region induced more westward moisture transport from the Atlantic, and consequently, more precipitation over central Eastern Patagonia and lower precipitation in central Western Patagonia and Southern Patagonia. To our knowledge, current GCMs simulating past climate appear to be incapable of realistically representing synoptic scale weather systems.

The current findings, have thus provided evidence that the westerlies rule is violated, especially under quasi-stationary synoptic easterly moisture flux conditions. Hence, such an interpretative climatic perspective is insufficient to infer present climate variability, and, ultimately, the interpretation of palaeoclimatic reconstructions in central/south Patagonia. Undoubtedly, future research will include modelled daily data in the analysis of 6000 and $9000 \mathrm{cal} \mathrm{yr} \mathrm{BP}$ and will qualitatively improve the present interpretation of the palaeoclimate inferred from proxy data in Patagonia.

Acknowledgements. D.A. thanks his colleagues at the PATO/PaLaTra project in Lago Cardiel that was co-founded by the US National Science Foundation and the Swiss National Science Foundation (grants 21-50862.97 and 2061704.00/1). R.C. acknowledges funding grants from the Argentinean funding agencies AGENCIA-MINCYT (grant PICT-2007-00438, PICT-2013-0043); CONICET (grant PIP 114-201001-00250); and UBA (grant UBACYT 20020100 101049). Also, thanks to the Argentine Weather Service who kindly provided Argentine station. We thank J. Moreteau and his crew for their tireless efforts to sail on Lago Cardiel and Potrok Aike under extremely harsh and windy conditions. E.A. thanks the Carmelite Order for their help.

\section{LITERATURE CITED}

Alessandro AP (2014) Incidence and trend of blocking action situations on the temperature and precipitation in Argentina. Atmósfera 27:141-163

Anselmetti FS, Ariztegui D, DeBatist M, Gebhardt AC and others (2009) Environmental history of southern Patagonia unraveled by the seismic stratigraphy of Laguna Potrok Aike. Sedimentology 56:873-892

Aravena J, Luckman BH (2009) Spatio-temporal rainfall pat- 
terns in Southern South America. Int J Climatol 29: 2106-2120

Ariztegui D, Anselmetti FS, Seltzer GO, Kelts K, D'Agostino K (2001) Identifying paleoenvironmental change across South and North America using high-resolution seismic stratigraphy in lakes. In: Markgraf V (ed) Interhemispheric climate linkages: present and past interhemispheric climate linkages in the Americas and their societal effects. Academic Press, San Diego, CA, p 227-240

Ariztegui D, Anselmetti FS, Gilli A, Waldmann N (2008) Late Pleistocene environmental changes in Patagonia and Tierra del Fuego-a limnogeological approach. In: Rabassa J (ed) The late Cenozoic of Patagonia and Tierra del Fuego. Developments in Quaternary Sciences Series 11 Elsevier Science, Oxford, p 241-253

Ariztegui D, Gilli A, Anselmetti FS, Goñi RA, Belardi JB, Espinosa S (2010) Lake-level changes in central Patagonia (Argentina): crossing environmental thresholds for Lateglacial and Holocene human occupation. J Quaternary Sci 25:1092-1099

Barrett BS, Garreaud R, Falvey M (2009) Effect of the Andes cordillera on precipitation from a midlatitude cold front. Mon Weather Rev 137:3092-3109

Barrett BS, Krieger BD, Barlow CP (2011) Multiday circulation and precipitation climatology during winter rain events of differing intensities in central Chile. J Hydrometeorol 12:1071-1085

Barros V, Mattio H (1978) Tendencias y fluctuaciones en la precipitación de la región patagónica. Meteorológica VIII:237-248

Berbery EH, Nuñez MN (1989) An observational and numerical study of blocking episodes near South America. J Clim 2:1352-1361

Berman AL, Silvestri G, Compagnucci R (2012) Eastern Patagonia seasonal precipitation: influence of Southern Hemisphere circulation and links with subtropical South American precipitation. J Clim 25:6781-6795

Berrisford P, Kallberg P, Kobayashi S, Dee D and others (2011a) Atmospheric conservation properties in ERAInterim. QJR Meteorol Soc 137:1381-1399

Berrisford P, Dee D, Poli P, Brugge R and others (2011b) The ERA-Interim archive, version 2.0. ERA report series. 1. Technical Report. ECMWF, Reading

Carrasco J, Casassa G, Rivera A (2002) Meteorological and climatological aspects of the Southern Patagonia Ice Cap. In: Casassa G, Sepúlveda FV, Sinclair RM (eds) The Patagonian icefields: a unique natural laboratory for environmental and climate change studies. Kluwer Academic, New York, NY, p 29-41

Dansgaard W (1964) Stable isotopes in precipitation. Tellus 16:436-468

Darwin C (1839) Voyages of the Adventure and Beagle, Vol. 3. Henry Colburn, London. http://darwin-online.org. ukconverted/pdf/1836_sketch_A73.pdf

Fletcher MS, Moreno PI (2012) Have the Southern Westerlies changed in a zonally symmetric manner over the last 14000 years? A hemisphere-wide take on a controversial problem. Quat Int 253:32-46

Garreaud R, Vuille M, Compagnucci R, Marengo J (2009) Present-day South American climate. Palaeogeogr Palaeoclimatol Palaeoecol 281:180-195

Gar reaud R, Lopez P, Minvielle M, Rojas M (2013) Largescale control on the Patagonian climate. J Clim 26: 215-230

Gilli A (2003) Tracking late Quaternary environmental change in southernmost South America using lake sediments of Lago Cardiel ( $\left.49^{\circ} \mathrm{S}\right)$, Patagonia, Argentina. PhD thesis, ETH Zurich (Switzerland). Diss ETH No. 15307 (http://e-collection.library.ethz.ch/eserv/eth:27187/eth27187-01.pdf)

Gilli A, Anselmetti FS, Ariztegui D, Bradbury JP, Kelts KR, Markgraf V, McKenzie JA (2001) Tracking abrupt climate change in the Southern Hemisphere: a seismic stratigraphic study of Lago Cardiel, Argentina (49 ${ }^{\circ} \mathrm{S}$ ). Terra Nova 13:443-448

Gilli A, Ariztegui D, Anselmetti FS, McKenzie JA, Markgraf V, Hajdas I, McCulloch RD (2005) Mid-Holocene strengthening of the southern westerlies in South America-sedimentological evidences from Lago Cardiel, Argentina $\left(49^{\circ} \mathrm{S}\right)$. Global Planet Change 49:75-93

Gilli A, Markgraf V, Anselmetti FS, Ariztegui D (2007) Comment on: G. Wenzens 2005: Glacier advances east of Southern Andes between the Last Glacial Maximum and 5,000 BP compared with lake terraces of the endorrheic Lago Cardiel (49 ${ }^{\circ}$, Patagonia, Argentina). Z. Geomorph. N. F. 49:433-454. Z Geomorph NF 51:135-137

Haberzettl T, Fey M, Lücke A, Maidana N and others (2005) Climatically induced lake level changes during the last two millennia as reflected in sediments of Laguna Potrok Aike, southern Patagonia (Santa Cruz, Argentina). J Paleolimnol 33:283-302

Hazeleger W, Wang X, Severijns C, Ştefănescu S and others (2012) EC-Earth V2. 2. Description and validation of a new seamless earth system prediction model. Clim Dyn 39:2611-2629

Hoffmann JA (1992) Das kontinentale Luftdruck- und Niederschlagsregime Südamerikas (The continental atmospheric pressure and precipitation regime of South America). Erdkunde 46:40-51

Kilian R, Lamy F (2012) A review of Glacial and Holocene paleoclimate records from southernmost Patagonia (49-55 S). Quat Sci Rev 53:1-23

Lamy F, Hebbeln D, Rohl U, Wefer G (2001) Holocene rainfall variability in southern Chile: a marine record of latitudinal shifts of the Southern Westerlies. Earth Planet Sci Lett 185:369-382

Lenaerts JT, van den Broeke MR, van Wessem JM, van de Berg WJ, van Meijgaard E, van Ulft LH, Schaefer MS (2014) Extreme precipitation and climate gradients in Patagonia revealed by high-resolution regional atmospheric climate modeling. J Clim 27:4607-4621

Markgraf V, Bradbury JP, Schwalb A, Burns SJ and others (2003) Reconstructing Holocene limnological and paleoenvironmental changes in Patagonia: paleoclimatic history of Lago Cardiel, Argentina $\left(49^{\circ} \mathrm{S}\right)$. Holocene 13: 581-591

Mayr C, Lücke A, Stichler W, Trimborn P and others (2007) Precipitation origin and evaporation of lakes in semi-arid Patagonia (Argentina) inferred from stable isotopes $\left(\delta^{18} \mathrm{O}, \delta^{2} \mathrm{H}\right)$. J Hydrol (Amst) 334:53-63

Mendes MCD, Trigo RM, Cavalcanti IFA, DaCamara CC (2008) Blocking episodes in the Southern Hemisphere: impact on the climate of adjacent continental areas. Pure Appl Geophys 165:1941-2003

McKenzie JA, Hollander DJ (1993) Oxygen-isotope record in recent carbonate sediments from Lake Greifen, Switzerland (1750-1986): application of continental isotopic indicator for evaluation of changes in climate and atmospheric circulation patterns. In: Swart PK, Lohwan KL, McKenzie JA (eds) Climate change in continental isotopic record. 
Geophys Monogr 78, Am Geophys Union, Washington, DC, p 101-111

Moreno PI (2004) Millennial-scale climate variability in northwest Patagonia over the last 15000 yr. J Quaternary Sci 19:35-47

Moreno PI, Francois JP, Moy CM, Villa-Martínez R (2010) Covariability of the Southern Westerlies and atmospheric $\mathrm{CO}_{2}$ during the Holocene. Geology 38:727-730

Moser BK, Stevens GR (1992) Homogeneity of variance in the two-sample means test. Am Stat 46:19-21

Pollock EW, Bush ABG (2013) Atmospheric simulations of southern South America's climate since the Last Glacial maximum. Quat Sci Rev 71:219-228

Prohaska F (1976) Climates of Central and South America. In: Schwerdtfeger W (ed) World survey of climatology. Elsevier, Amsterdam, p 13-72

Risi C, Bony S, Vimeux F (2008) Influence of convective processes on the isotopic composition $\left({ }^{18} \mathrm{O}\right.$ and $\left.\mathrm{D}\right)$ of precipitation and water vapor in the tropics. 2. Physical interpretation of the amount effect. J Geophys Res 113: D19306, doi:10.1029/2008JD009943

Rojas M, Moreno PI (2011) Atmospheric circulation changes and neoglacial conditions in the Southern Hemisphere mid-latitudes: insights from PMIP2 simulations at 6 kyr. Clim Dyn 37:357-375

Rozanski K, Araguás-Araguás L, Gonfiantini R (1992) Relation between long-term trends of oxygen-18 isotope composition of precipitation and climate. Science 258:981-985

Rozanski K, Araguás-Araguás L, Gonfiantini R (1993) Isotopic patterns in modern global precipitation. In: Swart

Editorial responsibility: Eduardo Zorita,

Geesthacht, Germany
PK, Lohwan KL, McKenzie JA (eds) Climate change in continental isotopic record. Geophys Monogr 78, Am Geophys Union, Washington, DC, p 1-36

Schneider U, Becker A, Finger P, Meyer-Christoffer A, Ziese M, Rudolf B (2014) GPCC's new land surface precipitation climatology based on quality-controlled in situ data and its role in quantifying the global water cycle. Theor Appl Climatol 115:15-40

Smith RB, Evans JP (2007) Orographic precipitation and water vapor fractionation over the southern Andes. J Hydrometeorol 8:3-19

Stine S, Stine M (1990) A record from Lake Cardiel of climate in southern South America. Nature 345:705-708

Tibaldi S, Molteni F (1990) On the operational predictability of blocking. Tellus 42:343-365

Trenberth KE (1991) Conservation of mass in ECMWF analysis. J Clim 4:707-722

Trenberth KE, Guillemot CJ (1998) Evaluation of the atmospheric moisture and hydrological cycle in the NCEP/ NCAR reanalysis. Clim Dyn 14:213-231

Wagner S, Widmann M, Jones JM, Mayer C, Ohlendorf C, Schäbitz F (2007) Transient simulations, empirical reconstructions and forcing mechanisms for the Mid-Holocene hydrological climate in Southern Patagonia. Clim Dyn 29:333-355

Zolitschka B, Anselmetti FS, Ariztegui D, Corbella H and others (2013) Environment and climate of the last 51000 years - new insights from the Potrok Aike maar lake Sediment Archive Drilling project (PASADO). Quat Sci Rev 71:1-12

Submitted: January 23, 2014; Accepted: November 3, 2014 Proofs received from author(s): January 29, 2015 